\title{
Applicability of GALE-86 Codes to Integral Pressurized Water Reactor Designs
}

\section{KJ Geelhood JP Rishel}

May 2012

\section{Pacific Northwest}

NATIONAL LABORATORY

Proudly Operated by Battelle Since 1965 


\title{
DISCLAIMER
}

This report was prepared as an account of work sponsored by an agency of the United States Government. Neither the United States Government nor any agency thereof, nor Battelle Memorial Institute, nor any of their employees, makes any warranty, express or implied, or assumes any legal liability or responsibility for the accuracy, completeness, or usefulness of any information, apparatus, product, or process disclosed, or represents that its use would not infringe privately owned rights. Reference herein to any specific commercial product, process, or service by trade name, trademark, manufacturer, or otherwise does not necessarily constitute or imply its endorsement, recommendation, or favoring by the United States Government or any agency thereof, or Battelle Memorial Institute. The views and opinions of authors expressed herein do not necessarily state or reflect those of the United States Government or any agency thereof.

\author{
PACIFIC NORTHWEST NATIONAL LABORATORY \\ operated by \\ BATTELLE \\ for the \\ UNITED STATES DEPARTMENT OF ENERGY \\ under Contract DE-AC05-76RL01830
}

Printed in the United States of America
Available to DOE and DOE contractors from the Office of Scientific and Technical Information,
P.O. Box 62, Oak Ridge, TN 37831-0062;
ph: (865) 576-8401
fax: $(865) 576-5728$
email: reports@adonis.osti.gov

\begin{abstract}
Available to the public from the National Technical Information Service, U.S. Department of Commerce, 5285 Port Royal Rd., Springfield, VA 22161 ph: (800) 553-6847 fax: (703) 605-6900 email: orders@ntis.fedworld.gov

online ordering: http://www.ntis.gov/ordering.htm
\end{abstract}

This document was printed on recycled paper. 


\section{Applicability of GALE-86 Codes to Integral Pressurized Water Reactor Designs}

KJ Geelhood

JP Rishel

May 2012

Prepared for

the U.S. Department of Energy

under Contract DE-AC05-76RL01830

Pacific Northwest National Laboratory

Richland, Washington 99352 



\section{Summary}

This report describes work that Pacific Northwest National Laboratory is doing to assist the U.S. Nuclear Regulatory Commission (NRC) Office of New Reactors (NRO) staff in their reviews of applications for nuclear power plants using new reactor core designs. These designs include small integral PWRs (IRIS, mPower, and NuScale reactor designs), HTGRs, (pebble-bed and prismatic-block modular reactor designs) and SFRs (4S and PRISM reactor designs).

To estimate routine radionuclide emissions for older reactor designs the NRC developed the GALE codes. The current released versions of the GALE codes for a pressurized water reactor (PWR) are reviewed with the objective of identifying features and limitations that would need to be modified to accommodate the technical review of iPWR and mPower ${ }^{\circledR}$ license applications and recommend specific changes to the code, NUREG-0017, and associated NRC guidance. This effort supports the licensing of iPWRs with a near-term focus on the $B \& W$ mPower ${ }^{\circledR}$ reactor design. While the focus of this review is on the mPower ${ }^{\circledR}$ reactor design, the review of the codes and the scope of recommended changes is expected to be universally applicable for other types of integral PWR designs.

This report provides a summary of the gaps in the versions of the GALE codes as they relate to iPWR designs, and for each gap, will propose what work could be performed to fill that gap and create a version of GALE that is applicable to integral PWR designs. The results are based on a detailed comparison between PWR and iPWR designs. Detailed information is provided on the GALE codes and its underlying computational basis. A determination is made as to the applicability of each of the bases to an iPWR design. The issues investigated in these efforts are a combination of a input from NRC staff, the results of comparing the PWR and iPWR designs, the parameters identified as having a large impact on the code outputs from a recent sensitivity study, and the main bases identified in NUREG-0017. 



\section{Acronyms and Abbreviations}

$\begin{array}{ll}\text { ALARA } & \text { As low as reasonably achievable } \\ \text { ANS } & \text { American Nuclear Society } \\ \text { AOO } & \text { Anticipated operational occurrence } \\ \text { BOA } & \text { Basic ordering agreement } \\ \text { BWR } & \text { Boiling Water Reactor } \\ \text { BWRGE } & \text { GALE code version for estimating Boiling Water Reactor Gaseous Effluent } \\ \text { BWRLE } & \text { GALE code version for estimating Boiling Water Reactor Liquid Effluent } \\ \text { B\&W } & \text { Babcock and Wilcox } \\ \text { DF } & \text { Decontamination factor } \\ \text { EPA } & \text { Environmental Protection Agency } \\ \text { EPRI } & \text { Electric Power Research Institute } \\ \text { GALE } & \text { Computer codes for computing Gaseous and Liquid Effluents } \\ \text { HTGR } & \text { High temperature gas reactor } \\ \text { iPWR } & \text { Integral pressurized water reactor } \\ \text { MWe } & \text { Megawatts electric } \\ \text { MWth } & \text { Megawatts thermal } \\ \text { NRC } & \text { U.S. Nuclear Regulatory Commission } \\ \text { NRO } & \text { New Reactors Office } \\ \text { ORIGEN } & \text { An isotopic depletion and decay analysis system } \\ \text { PC } & \text { Partition coefficient } \\ \text { PNNL } & \text { Pacific Northwest National Laboratory } \\ \text { PWR } & \text { Pressurized Water Reactor } \\ \text { PWRGE } & \text { GALE code version for estimating Pressurized Water Reactor Gaseous Effluent } \\ \text { PWRLE } & \text { GALE code version for estimating Pressurized Water Reactor Liquid Effluent } \\ \text { RSICC } & \text { Radiation Safety Information Computational Center } \\ \text { SCALE } & \text { A comprehensive modeling and simulation suite for nuclear safety analysis and design } \\ \text { SFR } & \text { Small fast reactor } \\ & \end{array}$





\section{Contents}

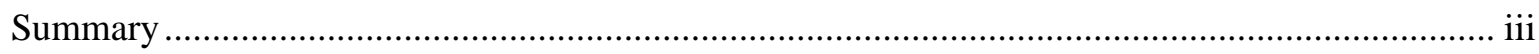

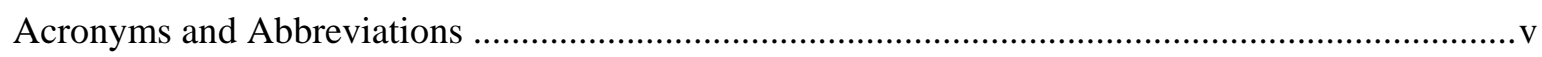

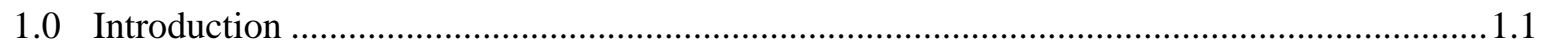

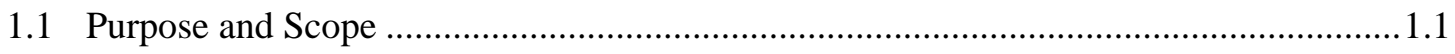

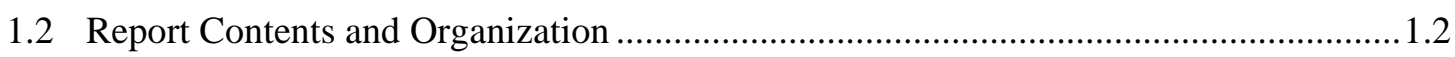

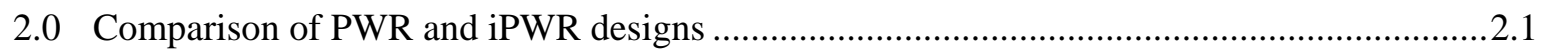

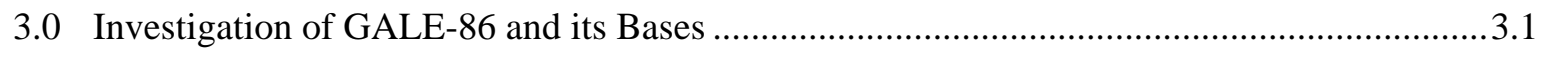

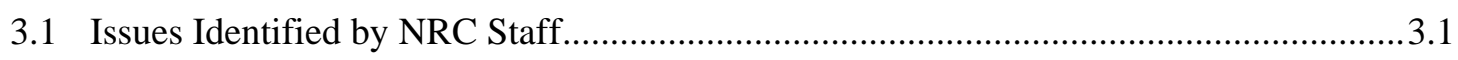

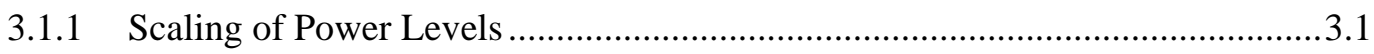

3.1.2 Radionuclide Concentration Levels................................................................... 3.4

3.1.3 Liquid and Gaseous Process Steam Treatment and Effluent Release..................3.5

3.1.4 Qualifiers on Radionuclides and Addition of Other Radionuclides .....................3.6

3.1.5 Nobel Gas Retention Times in Charcoal Delay Beds.........................................3.8

3.1.6 Radioiodine Filtration in Charcoal Decay Tanks ................................................ 3.8

3.1.7 Annualized Release Rates and Capacity Factor ................................................... 3.8

3.1.8 Adjustments for Anticipated Operational Occurrences ........................................ 3.9

3.1.9 Liquid and Gaseous Effluent Code Output Results and Presentation ................3.10

3.1.10 Code Structure and Operating Platform ........................................................10

3.2 Issues Identified by Comparison of PWR and iPWR Designs.......................................10

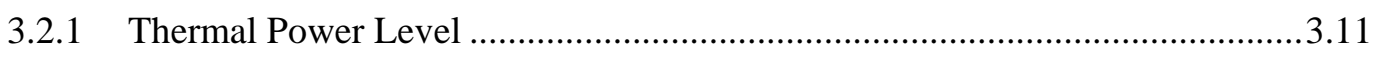

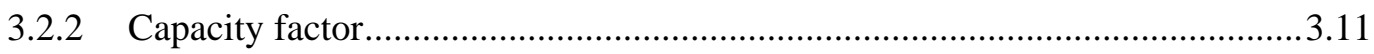

3.2.3 Coolant temperature ….............................................................................. 3.11

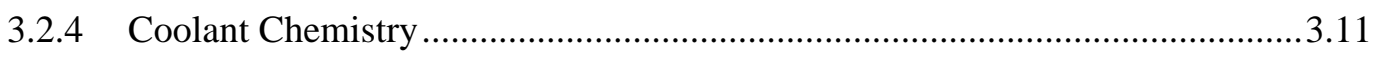

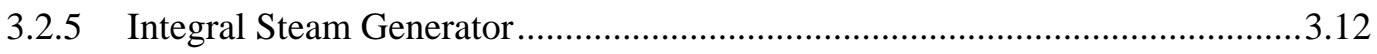

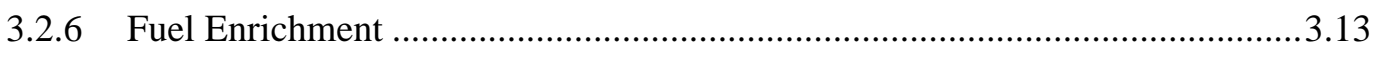

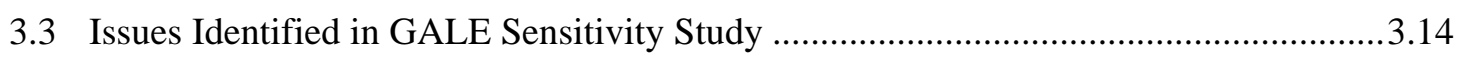

3.3.1 Capacity Factor ............................................................................................... 3.14

3.3.2 Nuclides in the Primary and Secondary Coolant ...............................................3.14

3.3.3 Radionuclide Release from Various Ventilation Systems before Treatment ...3.14

3.3.4 Iodine Release from the Main Condenser Exhaust...........................................3.16

3.3.5 Duration of Containment Air Cleanup, Percent of Air Treated, and Containment Purge Frequency .......................................................................... 3.16

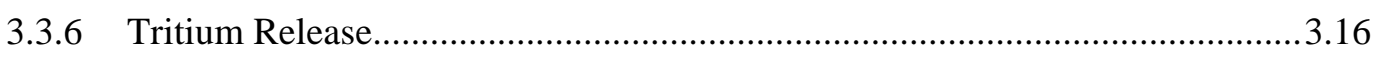

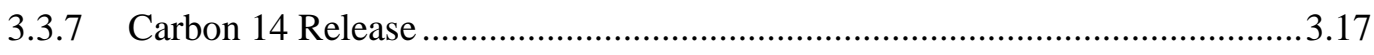

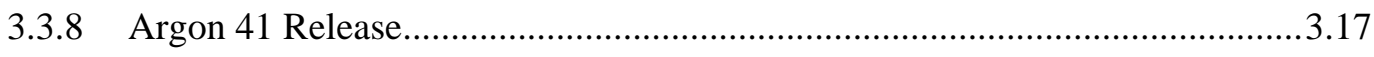

3.3.9 Nuclides in Detergent Waste ...................................................................... 
3.3.10 Decontamination Factors for Demineralizers, Evaporators and Reverse Osmosis Units.

3.3.11 Frequency and Extent of Unplanned Release ....................................................19

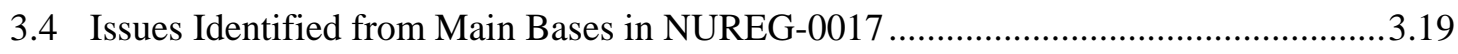

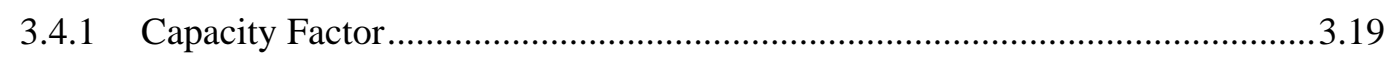

3.4.2 Radionuclide Concentrations in the Primary Coolant, Secondary Coolant, and

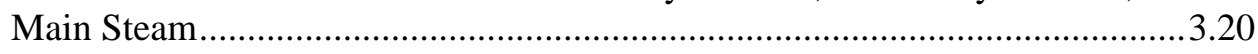

3.4.3 Radioiodine Releases from Building Ventilation Systems Prior to Treatment 3.20

3.4.4 Radioactive Particulate Releases from Building Ventilation Systems Prior to

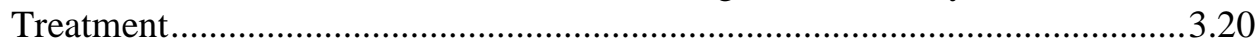

3.4.5 Nobel Gas Releases from Building Ventilation Systems .................................3.20

3.4.6 Containment Building Purge Frequency ........................................................2.20

3.4.7 Primary System Volumes Degassed per Year ......................................................2.21

3.4.8 Steam Generator Partition Coefficient...............................................................2.21

3.4.9 Radioiodine Releases from the Main Condenser Air Ejector Exhaust Prior to

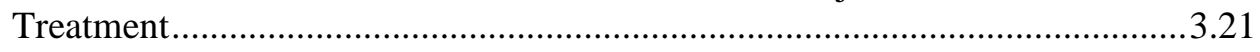

3.4.10 Containment Internal Cleanup System ........................................................2.

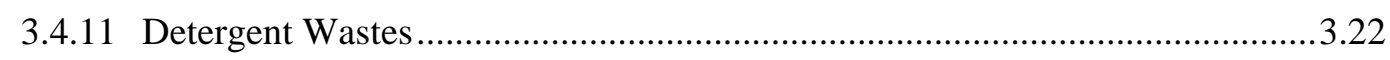

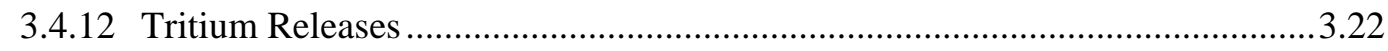

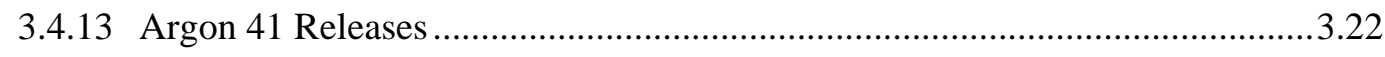

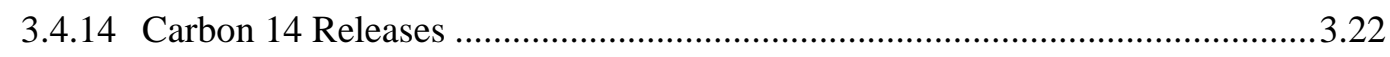

3.4.15 Decontamination Factor for Condensate Demineralizers....................................22

3.4.16 Primary Coolant Purification System Demineralizers .......................................3.22

3.4.17 Releases of Radioactive Material in Liquid Wastes from Turbine Building

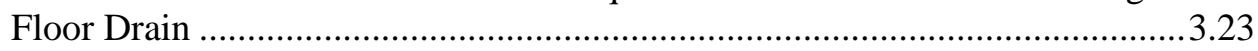

3.4.18 Regeneration of Condensate Demineralizers..................................................23.23

3.4.19 Adjustments to Liquid Radwaste Source Terms for Anticipated Operational Occurrences (AOO) ......................................................................................2.

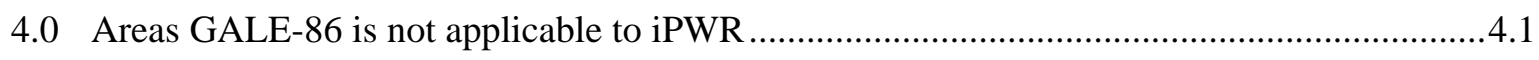

4.1 Changes Made to Reflect Modern PWR Design and Operations..................................... 4.1

4.2 Addition of New Nuclides to GALE Output.................................................................. 4.1

4.3 Hardwired Parameters in GALE-09 Changed to User Input........................................... 4.2

4.4 Changes to GALE Input and Output Format.............................................................4.4

4.5 Tritium Production and Release from Plants without Soluble Boron ............................ 4.5

4.6 Carbon-14 Production and Release ............................................................................. 4.5

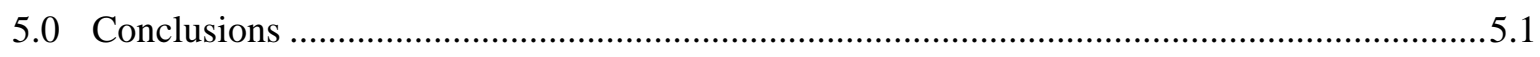

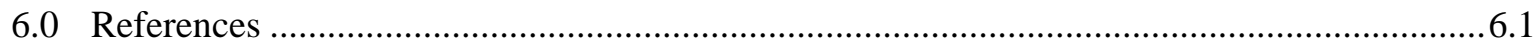




\section{Tables}

Table 2.1. Comparison of Parameters for Reference PWR and Reference iPWR .........................2.1

Table 3.1. Additional Nuclides to be added to GALE-86 .............................................................

Table 3.2. Calculated neutron flux at various locations in MPower ${ }^{\circledR}$ reactor ...............................3.13

Table 3.3. Iodine release to various buildings prior to treatment (currently used for I-131 and I-

$133)$

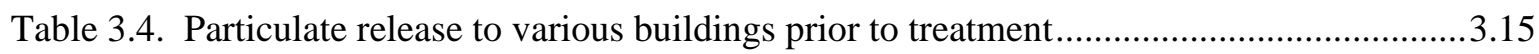

Table 3.5. Annual release of radioactive materials in untreated detergent waste .........................3.18

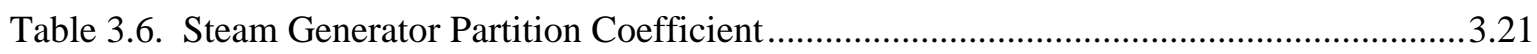

Table 4.1. Hardwired parameters in PWR GALE codes that should be changed to user input......4.3 



\subsection{Introduction}

This report describes work that Pacific Northwest National Laboratory ${ }^{1}$ is doing to assist U.S. Nuclear Regulatory Commission (NRC) staff in their reviews of small modular reactor license applications. NRC currently maintains a suite of codes that are used to calculate the gaseous and liquid effluents from nuclear power plants. These codes are called the GALE codes. The GALE codes consist of four models. PWRGE calculates gaseous effluents from pressurized water reactors (PWR). PWRLE calculates liquid effluents from PWRs. BWRGE calculates gaseous effluents from boiling water reactors (BWR). BWRLE calculates liquid effluents from BWRs. The current version of GALE being released by the Radiation Safety Information Computational Center (RSICC) is GALE-86 and is documented in NUREG-0016 rev. 1 and NUREG-0017 rev 1. This version is referred to in the applicable regulations, regulatory guides, and review plans, including Interim Staff Guidance DC/COL-ISG-5.

PNNL has done work for the NRC Office of Research and has created updated versions of GALE. GALE-08 was modified from GALE-86 to use the tables and adjustment equations described in ANS18.1 (1999) (Whelan et al. 2008) and GALE-09 was modified from GALE-08 to make GALE more applicable to modern reactor operations (Geelhood 2009). While both versions of these recent updates of the GALE code were provided to the NRC Office of Research at interim work products, neither revisions of the code have been endorsed by the NRC Office of New Reactors as acceptable methods for the purpose of preparing and submitting license applications for design certifications or combined licenses under 10 CFR Part 52.

The NRC Office of New Reactors Advanced Reactor Program (ARP) has entered into a Basic Ordering Agreement (BOA) with the PNNL to support NRC's resolution of policy issues, technical issues, pre-application activities, and development of the regulatory framework and supporting regulatory review infrastructure necessary to license various light-water and non-light-water advanced reactor designs. These designs include small integral pressurized water reactors (iPWR) (IRIS, mPower ${ }^{\circledR}$, and NuScale reactor designs), high temperature gas reactors, (pebble-bed and prismatic-block modular reactor designs) and small fast reactors (4S and PRISM reactor designs).

\subsection{Purpose and Scope}

The scope of this study is to determine if the GALE-86 codes are applicable to the iPWR designs. This study is necessary to support the licensing of iPWRs with a near-term focus on the B\&W mPower ${ }^{\circledR}$ reactor design. While the focus of this study is on the mPower ${ }^{\circledR}$ reactor design, the review of the codes and the scope of recommended changes will consider a revision of the codes that will make them universally applicable for other types of integral PWR designs. Because all the iPWR designs are pressurized water reactors, this study will only focus on the applicability and revisions to PWRGE and PWRLE in the GALE-86 suite.

This report details the limitations of the GALE-86 codes, identifies options for modifying the codes, recommends specific changes to the code and user manuals (NUREG-0017), and scopes out suggestions in revising directly relevant NRC guidance. The review of the codes and the scope of recommended

\footnotetext{
${ }^{1}$ Pacific Northwest National Laboratory is operated by Battelle for the U.S. Department of Energy under Contract DE-AC05-76RL01830.
} 
changes considered a revision of the codes that will make them universally applicable for other types of small integral PWR designs.

\subsection{Report Contents and Organization}

The ensuing sections of this report contain the results of the gap analysis performed on the GALE-09 codes as they apply to iPWR designs. Each location a gap is noted will be accompanied with a proposal of work that could be performed to fill this gap. The conclusion of this report contains a list of items that are needed to produce a version of PWRLE and PWRGE that is applicable to iPWR designs. Section 2.0 contains a comparison between a PWR design and an iPWR design. Section 3.0 contains an investigation of the computational basis of the GALE-09 codes and identifies areas where these bases are not applicable to the iPWR designs. The areas where the GALE-09 codes are not applicable to iPWR designs are summarized in Section 4.0 along with a proposal of work that could be performed to fill these gaps. The conclusions of the analysis are provided in Section 5.0.

Nuclides are interchangeably referred in this report to both by their full name (i.e. tritium, carbon-14) and by their abbreviation (i.e. H-3, C-14). The GALE outputs are generally listed using the abbreviated form. 


\subsection{Comparison of PWR and iPWR designs}

To determine the primary differences between a PWR and an iPWR as they relate to the ability of the GALE code to model the effluent releases, a table was constructed that details the similarities and differences between a PWR and an iPWR for reference plants. Table 2.1 shows this comparison for a Westinghouse 4 loop PWR and the mPower ${ }^{\circledR}$ iPWR.

Table 2.1. Comparison of Parameters for Reference PWR and Reference iPWR

\begin{tabular}{|c|c|c|c|}
\hline Item & $\begin{array}{l}\text { 1970’s vintage PWR } \\
\text { (reference case, } \\
\text { Westinghouse } 4 \text { loop) }\end{array}$ & $\begin{array}{c}\text { Modern PWR } \\
\text { (reference case, } \\
\text { Westinghouse } 4 \text { loop) }\end{array}$ & $\begin{array}{c}\text { iPWR } \\
\text { (reference case, } \\
\text { mPower }{ }^{\circledR} \text { ) } \\
\end{array}$ \\
\hline \multicolumn{4}{|l|}{ Reactor } \\
\hline Power & 1009 MWe 3027 MWth & 1123 MWe 3459 MWth & 180 MWe 530 MWth \\
\hline Capacity factor & $65-80 \%$ & $\sim 90 \%$ & $95 \%$ \\
\hline Steam generator & U-tube steam generator & U-tube steam generator & Internal once through \\
\hline Cycle length & 12 months & 18 months & 48 months \\
\hline \multicolumn{4}{|l|}{ Coolant } \\
\hline Inlet temperature & $550^{\circ} \mathrm{F}$ & $557.3^{\circ} \mathrm{F}$ & $564.5^{\circ} \mathrm{F}$ \\
\hline Outlet temperature & $620^{\circ} \mathrm{F}$ & $624.8^{\circ} \mathrm{F}$ & $608^{\circ} \mathrm{F}$ \\
\hline Flow rate & $2.61 \times 10^{6} \mathrm{lb} / \mathrm{ft}^{2}-\mathrm{hr}$ & $2.55 \times 10^{6} \mathrm{lb} / \mathrm{ft}^{2}-\mathrm{hr}$ & $1.39 \times 10^{6} \mathrm{lb} / \mathrm{ft}^{2}-\mathrm{hr}$ \\
\hline System Pressure & $2250 \mathrm{psi}$ & $2250 \mathrm{psi}$ & $2050 \mathrm{psi}$ \\
\hline \multicolumn{4}{|l|}{ Chemistry } \\
\hline Boron (Boric Acid) & Up to $1300 \mathrm{ppm}$ & Up to $1300 \mathrm{ppm}$ & None \\
\hline Chloride & $<20 \mathrm{ppb}$ & $<20 \mathrm{ppb}$ & Not determined \\
\hline Suspended solids & $<10 \mathrm{ppb}$ & $<10 \mathrm{ppb}$ & Not determined \\
\hline Aluminum & $<50 \mathrm{ppb}$ & $<50 \mathrm{ppb}$ & Not determined \\
\hline $\mathrm{LiOH}$ & $<3.25 \mathrm{ppm}$ & $<3.25 \mathrm{ppm}$ & Not determined \\
\hline Hydrogen & $25-50 \mathrm{cc} / \mathrm{kg}$ water & $25-50 \mathrm{cc} / \mathrm{kg}$ water & Not determined \\
\hline \multicolumn{4}{|l|}{ Fuel } \\
\hline Design & $15 \times 15$ & $17 \times 17$ & $17 \times 17$ \\
\hline Fuel rods & $\mathrm{UO}_{2}$ & $\mathrm{UO}_{2}$ & $\mathrm{UO}_{2}$ \\
\hline Burnable poison rods & None & $\begin{array}{l}\text { IFBA ( } \mathrm{UO}_{2} \text { with } \mathrm{ZrB}_{2} \\
\text { coating) } \\
\text { WABA }\left(\mathrm{Al}_{2} \mathrm{O}_{3} \text { with } \mathrm{B}_{4} \mathrm{C}\right. \\
\text { coating) }\end{array}$ & $\begin{array}{l}\mathrm{UO}_{2}-\mathrm{Gd}_{2} \mathrm{O}_{3} \\
\mathrm{Al}_{2} \mathrm{O}_{3} \text { with } \mathrm{B}_{4} \mathrm{C} \text { coating }\end{array}$ \\
\hline Length & $12 \mathrm{ft}$ & $12 \mathrm{ft}$ & $7.9 \mathrm{ft}$ \\
\hline Power Level & 5.5 to $6 \mathrm{~kW} / \mathrm{ft}$ & $5.53 \mathrm{~kW} / \mathrm{ft}$ & $3.78 \mathrm{~kW} / \mathrm{ft}$ \\
\hline Burnup & $\begin{array}{l}35 \mathrm{GWd} / \mathrm{MTU} \text { (assembly } \\
\text { average) } \\
40 \mathrm{GWd} / \mathrm{MTU} \text { (rod } \\
\text { average) }\end{array}$ & $\begin{array}{l}55 \text { GWd/MTU (assembly } \\
\text { average) } \\
62 \text { GWd/MTU (rod } \\
\text { average) }\end{array}$ & $\begin{array}{l}39 \mathrm{GWd} / \mathrm{MTU} \text { (assembly } \\
\text { average) }\end{array}$ \\
\hline Fuel Enrichment & $\sim 3 \%$ & $4.95 \%$ & $4.9 \%$ \\
\hline \multicolumn{4}{|l|}{ Control Rods } \\
\hline Type & $\begin{array}{l}\mathrm{B}_{4} \mathrm{C} \text { pellets and } \mathrm{Ag}-\mathrm{In}-\mathrm{Cd} \\
\text { alloy slugs sealed in } \\
\text { stainless steel tubes }\end{array}$ & $\begin{array}{l}\mathrm{B}_{4} \mathrm{C} \text { pellets and Ag-In-Cd } \\
\text { alloy slugs sealed in } \\
\text { stainless steel tubes }\end{array}$ & $\begin{array}{l}\text { Ag-In-Cd rodlets in sealed } \\
\text { stainless steel tubes }\end{array}$ \\
\hline \multicolumn{4}{|l|}{ Buildings } \\
\hline Containment Building & $\begin{array}{l}\text { Yes (called reactor } \\
\text { building) }\end{array}$ & $\begin{array}{l}\text { Yes (called reactor } \\
\text { building) }\end{array}$ & Yes \\
\hline $\begin{array}{l}\text { Reactor Service } \\
\text { Building }\end{array}$ & $\begin{array}{l}\text { Yes (called service and } \\
\text { Office Building) }\end{array}$ & $\begin{array}{l}\text { Yes (called service and } \\
\text { Office Building) }\end{array}$ & Yes \\
\hline Control Building & Yes & Yes & Yes \\
\hline
\end{tabular}




\begin{tabular}{|c|c|c|c|}
\hline Item & $\begin{array}{l}\text { 1970's vintage PWR } \\
\text { (reference case, } \\
\text { Westinghouse } 4 \text { loop) }\end{array}$ & $\begin{array}{c}\text { Modern PWR } \\
\text { (reference case, } \\
\text { Westinghouse } 4 \text { loop) }\end{array}$ & $\begin{array}{c}\text { iPWR } \\
\text { (reference case, } \\
\text { mPower }{ }^{\circledR} \text { ) }\end{array}$ \\
\hline $\begin{array}{l}\text { Fuel Handling } \\
\text { Building }\end{array}$ & $\begin{array}{l}\text { Yes (called auxiliary } \\
\text { building) }\end{array}$ & $\begin{array}{l}\text { Yes (called auxiliary } \\
\text { building) }\end{array}$ & Yes \\
\hline Turbine Building & Yes & Yes & Yes \\
\hline $\begin{array}{l}\text { Radioactive Waste } \\
\text { Building }\end{array}$ & No & No & Yes \\
\hline $\begin{array}{l}\text { Diesel Generator } \\
\text { Buildings }\end{array}$ & Yes & Yes & No \\
\hline $\begin{array}{l}\text { Natural Draft Cooling } \\
\text { Towers }\end{array}$ & Yes & Yes & No \\
\hline
\end{tabular}

It can be seen from this comparison that the primary differences between 1970's vintage reactors and modern reactors are; capacity factor has increased, fuel enrichment has increased, the use of burnable poisons has begun, fuel burnup is higher, and the fuel designs have changed. As far as the predictions of GALE-86 are concerned, the biggest differences will be due to changes to empirical parameters due to reduced releases from modern plants due to improved "best practices" and the "As Low as Reasonably Achievable” (ALARA) philosophy.

Most iPWR designs, including mPower ${ }^{\circledR}$, are based on modern reactor operations and fuel designs. The primary differences between modern PWRs and iPWRs are in the size of the reactors and in the fact that the iPWR has an integral steam generator. Beyond this point, the two reactors have very similar parameters and buildings. The design differences shown in this table and their impacts on the GALE-86 predictions of gaseous and liquid effluents will be discussed in detail in Section 3.2. 


\subsection{Investigation of GALE-86 and its Bases}

This section contains the results of the investigation of GALE-86 and its computational bases as they relate to the ability to model iPWR reactor designs. Although the mPower ${ }^{\circledR}$ design is the reference design for this investigation, any changes proposed as a result of this investigation would be designed to make the GALE-86 codes applicable to any iPWR reactor design.

In order to fully investigate the applicability of the GALE-86 codes for iPWR reactor designs, issues were identified and investigated from four sources. The first source was a list of issues identified by NRC staff; these issues are discussed in Section 3.1. The second source is issues that have been identified by the comparison of the PWR and iPWR design in Section 2.0; these issues are discussed in Section 3.2. The third source is issues that have been identified in a recent sensitivity study of the hardwired parameters in GALE-08 (Geelhood et al, 2008); these issues are discussed in Section 3.3. The forth source is issues related to the built in parameters included in the GALE codes that have been identified in NUREG-0017; these issues are discussed in Section 3.4.

\subsection{Issues Identified by NRC Staff}

The NRC staff developed a base list of major features and limitations for this evaluation to consider in a possible future revision of the GALE-86 codes. This input from NRC was used as a starting point for the detailed PNNL review based on the specifics of the computational basis of the GALE codes.

This section provides an analysis of each of the issues that has been identified by NRC staff. Any issue that reveals a gap in the applicability of the GALE-86 codes will be further discussed in Section 4.0 along with a discussion of the work that would be required to fill that gap.

\subsubsection{Scaling of Power Levels}

The NRC staff noted that the power level for the mPower ${ }^{\circledR}$ reactor was significantly lower than for a typical PWR (530 MWth vs. 3400 MWth). A concern was raised that the correlations that use the power level in GALE-86 may not be valid for very low power levels. The source code for PWRGE and PWRLE were examined, and it was found that both codes use the thermal power level for two calculations.

First, the thermal power level is used in the tritium calculation. GALE-86 uses a value of 0.4 $\mathrm{Ci} /$ year/MWth. The GALE codes were recently updated and GALE-09 assumes that $0.27 \mathrm{Ci} /$ year/MWth will be released from a reactor (Geelhood, 2009). More calculations are used to determine the amount released in the liquid and gaseous pathways. Tritium cannot be readily removed by any cleanup system and it has a relatively long half life (12.3 years). Therefore the majority of tritium created in the reactor will be released to the environment. The sources of tritium in a PWR come from coolant soluble boron, secondary source rods, coolant soluble lithium, coolant deuterium, control rods, burnable poison rods containing boron, and fuel. In a typical PWR, the majority of the tritium released to the coolant is from the coolant soluble boron and lithium and secondary source rods. Since the mPower ${ }^{\circledR}$ design will not used soluble boron, and as a result will use less soluble lithium, the GALE assumption for tritium based on the power level will not be valid. It will likely over-predict the coolant tritium concentration and release. A discussion of tritium release in iPWRs is included in Section 3.2.4. 
Second, the thermal power level is used in the GALE-86 codes in the adjustments made to the radionuclide concentrations in the primary and secondary coolant. ANS-18.1 (1984) and ANS-18.1 (1999) provide a table of concentrations of various radionuclides in the primary and secondary coolant for a reference PWR. The two versions of this standard also provide equations and parameters to adjust these concentrations for a different reactor based on a number of parameters including thermal power level. GALE-86 has previously been found to not be fully in compliance with ANS-18.1 (1984) ) (Whelan et al., 2008). It is recommended that these issues be addressed and the nuclide concentrations be updated. GALE-08 and GALE-09 use the concentrations from the 1999 version of this standard and the scaling methodology provided in this standard to determine the radionuclide concentrations in the primary and secondary coolant. This recommendation is discussed in Section 4.1.

The scaling method that is described in ANS-18.1 (1999) has been examined by PNNL and appears to be a reasonable way to scale the nuclide concentrations. The ANS-18.1 standard did not state any limits that should be applied to this scaling method. PNNL staff submitted a Standards Inquiry Submittal From to the American Nuclear Society Standards Committee to ask if they think the scaling method described in ANS-18.1 (1999) is applicable to a 530 MWth reactor such as mPower ${ }^{\circledR}$. ANS has acknowledged receiving this request but has not provided an answer to date.

The ANS-18.1 standard adjusts the concentration of radionuclides in the primary and secondary coolant from those given for the reference reactor using three different parameters. These parameters are: reactor power, mass of water in the reactor, and the removal rate of nuclides by the coolant purification systems. The concentrations are increased proportional to the ratio of the total reactor power to the reference reactor power. It is thought that more fuel in the reactor will lead to a linear increase in power and a linear increase in radionuclides. The concentrations are increased proportional to the ratio of the reference coolant mass to the actual coolant mass. An increase in coolant mass will lead to a decrease in coolant concentration as more water is available to dilute the radionuclides. Finally, since different reactors have different primary coolant purification systems, the concentrations are adjusted proportionally to the ratio of the removal rate of the reference reactor to the actual removal rate. A plant with a larger removal rate than the reference plant will have a lower coolant concentration. The overall equation used is shown below. There are different parameters for the removal rates of different classes of elements. The general equation is shown below:

$$
\text { Conc }=\text { Conc }_{r e f} \frac{P}{P_{r e f}} \frac{M_{r e f}}{M} \frac{R_{r e f}}{R}
$$

Where:

$\begin{array}{lll}\text { Conc, } \text { Conc }_{\text {ref }} & = & \text { Concentration of coolant in current and reference reactors, respectively } \\ P, P_{\text {ref }} & = & \text { Total thermal power for current and reference reactors, respectively } \\ M, M_{\text {ref }} & = & \text { Mass of coolant in current and reference reactors, respectively } \\ R, R_{\text {ref }} & = & \text { Removal rate for elements in current and reference reactors, respectively }\end{array}$


In order to determine if these adjustments are appropriate, it is important to examine the source of radioactive material in the coolant. The three processes that result in radioactive isotopes in the primary coolant are (1) fission products which have been released from the fuel pellets and leak from defective fuel rods or diffuse from in-tact fuel rods into the primary coolant; (2) fission products which originate in the primary coolant as a result of the fissioning of "tramp" uranium on fuel surfaces; and (3) activation of corrosion products, chemical additives, and the coolant itself. The thermal power of the reactor is a reasonable metric to scale the fission products, as the thermal power is a function of the overall fission rate for the fuel in the reactor and thus a function of the fission product creation. The amount of "tramp" uranium in the coolant is an extremely small quantity relative to the uranium in the fuel and the fission products that come from this are well within the uncertainty of the fission products that come from the fuel rods. The quantity of activation products that come from activation of the coolant is proportional to the neutron flux, which is related to the overall core power, thus the core power is acceptable for scaling these nuclides. Finally, the activation products that come from corrosion products derive mainly from the stainless steel components in the primary loop. Corrosion products are carried from the vessel wall, the reactor internals and the pipes in the steam generator into the active core region where neutron flux is high and can form various radionuclides in the coolant. The quantity of stainless steel in the reactor internals and the pipes in the steam generator are reasonably expected to increase with increasing power leading to more corrosion products being available for activation in a larger reactor. The reactor vessel wall surface area per unit power in a small reactor is greater than in a large reactor, which could lead to more corrosion products per unit power in a small reactor. However, the majority of corrosion products derive from the reactor steel in the reactor internals and the pipes in the steam generator. Therefore it is reasonable to scale the corrosion products by the total thermal power as well.

Unless informed otherwise by the ANS standards committee, PNNL concludes based on the above discussion that the current scaling methodology described in ANS-18.1 is reasonable to use to scale the provided nuclide concentrations to low power levels. The quantity of radionuclides is scaled according to reactor power. The concentration of this quantity is determined by scaling according to the amount of water available. A final scaling is performed based on the removal rate of the coolant purification system relative to that of the reference reactor. This does not necessarily mean that the tables provided in ANS18.1 (1999) are applicable to the mPower design. This issue will be discussed in Section 3.1.2.

NRC staff expressed concern that there were certain limits of applicability on the parameters built into the code. PNNL has examined the code and has found that the primary coolant concentrations will be adjusted from those in the tables in ANS-18.1 (1999) if any of the following is true:

- Thermal power is less than 3000 MWth or greater than 3800 MWth.

- Mass of primary coolant is less than 500,000 lbs or greater than 600,000 lbs

- Primary system letdown rate is less than $32,000 \mathrm{lb} / \mathrm{hr}$ or greater than $42,000 \mathrm{lb} / \mathrm{hr}$.

- Shim bleed rate is less than $250 \mathrm{lb} / \mathrm{hr}$ or greater than $1,000 \mathrm{lb} / \mathrm{hr}$.

- Letdown cation demineralizer flow is greater than 7,500 lb/hr.

In the case of mPower ${ }^{\circledR}$, it is likely that all these statements will be true. In this case GALE will adjust the coolant radionuclide concentrations from those listed in ANS-18.1 according to the methodology in ANS-18.1 using all these input parameters including the lower mass of primary coolant. 
NRC staff noted that mPower ${ }^{\circledR}$ will have continuous purification of reactor coolant during normal operation (minimum of one RCS volume every eight hours) with purification equipment inside containment to minimize coolant leaving containment. PNNL notes that GALE-86 currently has the option on the $4^{\text {th }}$ input line to input the primary system letdown rate to the purification demineralizers. The nuclide concentration in the primary coolant is adjusted based on the input letdown rate and the removal rates specified in ANS-18.1(1999). In order to model continuous purification of the reactor coolant with one RCS volume being replaced every eight hours, the user should input a letdown rate that corresponds to one RCS volume in eight hours. In addition, the user can specify the flow rate through the cation demineralizer that is used to control cesium in the primary coolant. This rate is specified on the $5^{\text {th }}$ input line. Finally, on line 30 the user can select continuous degasification of the full letdown flow. Using this option and selecting a primary system letdown rate that corresponds to one RCS volume every eight hours, the user can model this capability in GALE-86.

\subsubsection{Radionuclide Concentration Levels}

The NRC staff noted that the PWR-GALE codes are based on an earlier version of ANS-18.1. It is noted that GALE-08 and GALE-09 have been updated and include the coolant concentrations and scaling methodology specified in ANS-18.1 (1999). The ANS standards committee was contacted to determine what the status is on a new updated to ANS-18.1. The standards administrator informed PNNL that the ANS-18.1 project is on hold until they can find new data. They have contacted several organizations and have been told that this information is not available. Work is underway to contact utilities individually, but many utilities may consider this information proprietary. Based on this, PNNL concludes that it is best to retain the use of the most current ANS-18.1 (1999) radionuclide concentration levels in GALE as discussed in Section 4.1.

The NRC staff raised a concern that the values in ANS-18.1 may not be applicable to the mPower design. PNNL investigated these nuclides and has determined that these nuclides come from three sources. The three processes that result in radioactive isotopes in the primary coolant are (1) fission products which have been released from the fuel pellets and leak from defective fuel rods or diffuse from in-tact fuel rods into the primary coolant; (2) fission products which originate in the primary coolant as a result of the fissioning of "tramp" uranium on fuel surfaces; and (3) activation of corrosion products, chemical additives, and the coolant itself fission products from the fuel, and activation products from the steel core components and the coolant. As discussed in Section 3.1.1, the fission products from the "tramp" uranium are well within the uncertainty of the fission products from the fuel and can be ignored in this application. Since the fuel and the steel core components for mPower are very similar to a PWR, it is reasonable to assume that the concentrations of fission products and stainless steel activation products will be similar once adjusted with the appropriate adjustment equations. One difference noted in Section 3.1.2 is that the surface area of the vessel wall per unit power is greater for a small reactor than for a large reactor. Corrosion products are carried from the vessel wall, the reactor internals and the pipes in the steam generator into the active core region where neutron flux is high and can form various radionuclides in the coolant. The quantity of steel in the reactor internals and the pipes in the steam generator are reasonably expected to increase with increasing power leading to more corrosion products being available for activation in a larger reactor. The reactor vessel wall surface area per unit power in a small reactor is greater than in a large reactor which could lead to more corrosion products per unit power in a small reactor. However, the majority of corrosion products derive from the reactor steel in the reactor internals and the pipes in the steam generator. Therefore it is reasonable to scale the corrosion products by the total 
thermal power as well. The one coolant activation product, tritium (H-3), will likely be different due to the lack of soluble boron as noted by NRC staff in mPower. This concentration will have to be updated.

The NRC staff raised concerns that the 4-year cycle length or the enrichment of $4 \%$ to $5 \%$ U-235 in the fuel could cause a difference in the nuclide concentrations in the coolant. It is noted that modern PWR fuel contains fuel with up to 5\% U-235 enrichment and that the anticipated fuel enrichments are not different from that of PWR fuel. Although GALE-86 is based on measurements from reactors with lower enriched fuel, the enrichment is not expected to impact radionuclide concentration discussed in Section 3.2.6. In addition, it is noted that the cycle length does not have a large impact on the primary and secondary coolant concentrations. Water injections and removals are made to the primary coolant throughout the cycle to maintain proper coolant chemistry. Therefore, concentrations do not build up in the reactor coolant system with a total cleanup at the end of the cycle. Rather, the water drained from the primary coolant loop is continuously drained and the drained water sent through decontamination systems.

The NRC staff noted other differences including different continuous coolant purification and letdown rates; different containment cleanup and purge rates; different waste gas treatment and holdup systems; a single once-through steam generator (SG); different SG blowdown rates, and different feedwater fractional treatment through condensate demineralizers. For all these noted differences, the user already has the capability in GALE-86 to input the required parameters to model these differences. With regard to the once-through steam generator, GALE-86 already allows the user to select if there is a once-through steam generator or a u-tube steam generator as current PWRs have both of these type steam generators. The only thing that could be different is some of the leakage terms that are fixed in GALE86. These will be examined in Section 3.4.

\subsubsection{Liquid and Gaseous Process Steam Treatment and Effluent Release}

The NRC staff noted that there are no definitive details on how the reactor design will treat liquid and gaseous process streams before being released as effluents. The current mPower ${ }^{\circledR}$ design looks very similar to a PWR in its plant layout downstream from the steam generator. Steam from the steam generators from up to two reactors goes into the turbine building. Each steam source will have its own turbine. The other buildings are very similar to a PWR as shown in Table 2.1 with the exception that the mPower ${ }^{\circledR}$ design does not have cooling towers or a diesel generator building.

Regardless of the similarity in plant layout, it is noted that PWRLE allows for six liquid waste streams including: shim bleed, equipment drain waste, clean waste, dirty waste, blowdown waste, and regenerent wastes. The user is responsible for inputting the flow rate for each waste stream as well as the activity, decontamination factors and processing and discharge time. The GALE-86 documentation provides guidance in how to calculate effective values when two waste streams are combined. This flexibility in PWRLE will allow the user to correctly model whatever liquid waste processing systems are used.

Likewise in the PWRGE code, the user inputs generic parameters for holdup time for noble gases stripped from the coolant and for iodine and particulate release fractions and building volumes from the air handling units on each building. This flexibility in PWRGE will allow the user to correctly model whatever gas waste processing systems are used. 
The NRC staff noted that most of the iPWR designs, including mPower ${ }^{\circledR}$ have options for multiple modules on one site. The mPower ${ }^{\circledR}$ design includes options for a two-unit site or a four-unit site. For both of these options two units feed one turbine and then one of each downstream support buildings are present for those two units. In this case, PNNL would recommend that GALE could be used to model two reactors as one larger unit since they both feed the same turbine. This is similar to a PWR with multiple steam generators that feed one turbine. For the four-unit site, one GALE input would be used for units 1 and 2, and a second for units 3 and 4 since their support buildings are completely separate and similar to a 2 unit PWR site.

However, as the design evolves and the radwaste system is finalized, a decision can be made regarding how to best model each unit. GALE-86 updated with the corrections recommended in Section 4.0 has the flexibility in the input to specify flow rates, removal efficiencies, and holdup times for many different waste treatment systems for all the waste streams and gas cleanup systems regardless of the relative location of buildings.

\subsubsection{Qualifiers on Radionuclides and Addition of Other Radionuclides}

The NRC staff noted that some of the radionuclides included in ANS-18.1 (1999) and in GALE-86 are not due to fission products, but rather due to activation of fission products that have decayed in the fuel. For example, the fission product, Xe-133 decays to Cs-133 and then can be activated through neutron reaction to Cs-134. Although ANS-18.1 (1999) does not address the process through which these radionuclides were produced or came to be in the primary or secondary coolant, all the creation processes including fission products and activation products of the fission products, the stainless steel components, and the coolant are implicitly included in this list as it is based on measured data from operating plants. With regard to scaling, as long as the sources of these nuclides remain $\left(\mathrm{UO}_{2}\right.$ fuel, zirconium alloy cladding, stainless steel reactor components, and water for coolant), it is expected that these nuclides will be present and the described scaling factors will be applicable. The only difference for mPower ${ }^{\circledR}$ is the lack of soluble boron which has an impact on the tritium concentration as discussed in Sections 3.1.1 and 3.2.4. GALE-86 contains tables of nuclear data for the nuclides so it can calculate radioactive decay of these nuclides as the waste streams containing these nuclides are processed and held up. However, once the nuclides are out of the reactor core, there is no significant neutron flux that would be expected to build up any new activation products.

The NRC staff noted that there is a need to consider additional radionuclides beyond those already considered. These nuclides are: Tc-99, I-129, I-132, I-134, I-135 and F-18. These radionuclides are shown in Table 3.1 along with their half life, and an indication of if these nuclides are included in the tables in ANS-18.1 and in the GALE-86 nuclear data file. 
Table 3.1. Additional Nuclides to be added to GALE-86

\begin{tabular}{llll}
\hline Nuclide & Half Life & $\begin{array}{l}\text { Nuclide in ANS-18.1 } \\
(\mathbf{1 9 9 9 )}\end{array}$ & $\begin{array}{l}\text { Nuclide in GALE-86 } \\
\text { Nuclear Data File }\end{array}$ \\
\hline Tc-99 & 209,000 years & No & Yes \\
Tc-99m & 6 hours & Yes & Yes \\
I-129 & $17,000,000$ years & No & Yes \\
I-132 & 2.3 hours & Yes & Yes \\
I-134 & 53 minutes & Yes & Yes \\
I-135 & 6.7 hours & Yes & Yes \\
F-18 & 110 minutes & No & No \\
\hline
\end{tabular}

For those nuclides that are included in ANS-18.1 tables and in the GALE-86 nuclear data file, these nuclides can easily be added to the GALE calculations. These were not included in the original GALE-86 output because their half lives are so short that for normal operation, they will have completely decayed prior to release. For those that are not in ANS-18.1, the coolant concentration of the stable isotopes (I129 and Tc-99) can be calculated. Once the coolant concentrations are calculated, the release of these isotopes can be added according to the same procedure used for other isotopes of the same element that are already in GALE (e.g. I-132 will behave identically to I-131 except for its radioactive decay which is included in the nuclear data file and will be included in the appropriate subroutines in GALE).

Additionally, a recommendation for how to address F-18 can be made. The full recommendations for how these nuclides will be added to GALE are discussed in Section 4.2.

The NRC staff noted that the PWR-GALE code has only minimal data to support the current assumption for $\mathrm{C}-14$ release. The staff also notes that it may be necessary for the code to report what fraction of the $\mathrm{C}-14$ is released as organic compounds and what fraction of the $\mathrm{C}-14$ is released as $\mathrm{CO}_{2}$.

PNNL notes that GALE-86 uses a value of 7.3 Ci/yr for carbon-14 release based on measurements from seven reactors between 1975 and 1978. This value was updated in GALE-09. NRC does not require licensees to report carbon-14 in their annual radioactive release reports. Because of this, it was not possible to compile a large data set of carbon-14 release values. A search of literature published since the time of the last survey was performed to determine if more recent data would indicate a different carbon-14 release. An EPRI report (Vance et al., 1995) presented data from two U.S. and six German PWRs in 1984 and 1985 that had an average carbon-14 release of $5.9 \mathrm{Ci} / \mathrm{yr}$. Another source (Yim et al., 2006) referenced an EPA study in 1981 that found the release to be about $5.0 \mathrm{Ci} / \mathrm{yr}$. The value in the GALE-09 code was decreased from $7.3 \mathrm{Ci} / \mathrm{yr}$ to $5.9 \mathrm{Ci} / \mathrm{yr}$ based on average values from the most recent surveys (Geelhood, 2009). This value also compared well with value from the aforementioned EPA study.

The NRC staff noted that there has been a recent EPRI report (Kim 2010) on the release of C-14. This report recommends a methodology for calculating C-14 releases as a function of reactor power level. This methodology also includes a way to predict the $\mathrm{C}-14$ release fraction as organics and as $\mathrm{CO}_{2}$. $\mathrm{PNNL}$ has reviewed this methodology and agrees that it is a reasonable approach to calculating C-14 release and the fraction releases as organics and as $\mathrm{CO}_{2}$, but that all the above methods contain a large degree of uncertainty. If requested, the GALE-86 code can be updated to include this methodology as it is more fundamental than the previous methodology and since it can be scaled with reactor power level, so it can be applied to iPWR designs. The recommended updates to GALE-86 are discussed in Section 4.6. 


\subsubsection{Nobel Gas Retention Times in Charcoal Delay Beds}

The NRC staff noted that there may be a need to revise the recommended dynamic adsorption coefficients in GALE-86 using updated information. PNNL notes that these values are recommendations and ultimately the user inputs the holdup times for Xe and Kr. Additionally, a study has already been performed on the applicability of these dynamic adsorption coefficients (Geelhood, 2008). The result of this study was that little work has been done in the field of activated charcoal that would improve on these dynamic adsorption coefficients since the original systems were installed. Several more recent measurements of dynamic adsorption coefficients showed reasonable agreement with the data used in the GALE derivation. Based on this, it was recommended that the table of recommended dynamic adsorption coefficients shown NUREG-0017 be retained in the user input guidelines. These guidelines are also expected to be applicable to iPWR designs. Nevertheless, the user retains the flexibility to input holdup times outside of these guidelines.

The NRC staff had a comment about the NUEG-0017 presentation of the Ar-41 bases and related data. PNNL notes that more data have been collected and a new value of Ar-41 has been calculated and included in GALE-09. This is discussed in Section 3.3.8.

\subsubsection{Radioiodine Filtration in Charcoal Decay Tanks}

The NRC staff noted that the code assigns default removal efficiencies for radioiodines in carbon beds. The removal efficiencies are based on RG 1.140 (U.S. NRC 1979) for filters of specific depths, 2, 4 , and 6 inches. The staff feels there is a need to revise such information and provide default efficiencies for charcoal delay beds used in offgas waste processing system. PNNL notes that although many nuclide removal efficiencies are hard wired in the GALE PWR code, some of these specific removal efficiencies can be modified in the user inputs. In the GALE PWR code, the user is required to enter the iodine removal efficiency for any charcoal adsorbers in use in the fuel handling and auxiliary buildings. In addition, removal efficiencies for charcoal adsorbers in use in the containment internal cleanup system, high volume purge, and low volume purges must be specified. PNNL also notes that RG 1.140 was updated in 2001 (U.S. NRC 2001) and the revised table is provided as user guidance in the upcoming revision of NUREG-0017. These guidelines are also expected to be applicable to iPWR designs. Nevertheless, the user retains the flexibility to input removal efficiencies outside of these guidelines.

\subsubsection{Annualized Release Rates and Capacity Factor}

The NRC staff noted that the GALE-86 code assigns a built-in default value of 0.8 for the plant capacity factor. Possible issues include 1) having a built-in capacity factor and 2) how the capacity factor is used in the calculations. It is noted that in GALE-09, the built-in capacity factor has been changed to 0.9 based on an average plant capacity factor for the PWR and BWR fleet of around 0.9 for the past ten years (Geelhood, 2009). Since the mPower ${ }^{\circledR}$ design is planning to have a 95\% capacity factor, PNNL concludes that the capacity factor in GALE-86 should be changed to be an input parameter rather than a fixed value. This change is discussed in Section 4.3.

The source code for GALE-86 was examined to determine where the capacity factor is used. The plant capacity factor is not included in PWRLE. The plant capacity factor is used in PWRGE and is used to reduce the processing times applied to cleanup of various gaseous waste streams. 
It is noted that the annual release rate of radioiodine from various buildings during normal operation and at shutdown are empirically derived and based on surveys taken when capacity factors of $80 \%$ were common. If the capacity factor is increased due to longer cycles, then the annual release rate during normal operation should increase and the annual release rate during shutdowns should decrease. The following equations should be used to adjust the releases built into GALE-86 based on the input values of capacity factor.

$$
\begin{aligned}
& R(\text { norm })_{\text {adjusted }}=\frac{C F}{0.8} R(\text { norm })_{\text {base }} \\
& R(\text { shutdown })_{\text {adjusted }}=\frac{1-C F}{0.2} R(\text { shutdown })_{\text {base }}
\end{aligned}
$$

Where:

$\begin{array}{lll}\mathrm{R}(\text { norm })_{\text {adjusted }} & = & \text { Adjusted release rate during normal operations, } \mathrm{Ci} / \mathrm{yr} / \mu \mathrm{Ci} / \mathrm{g} \\ \mathrm{R}(\text { norm })_{\text {base }} & = & \text { Currently used release rate during normal operations, } \mathrm{Ci} / \mathrm{yr} / \mu \mathrm{Ci} / \mathrm{g} \\ \mathrm{R}(\text { shutdown })_{\text {adjusted }} & = & \text { Adjusted release rate during shutdown, } \mathrm{Ci} / \mathrm{yr} / \mu \mathrm{Ci} / \mathrm{g} \\ \mathrm{R}(\text { shutdown })_{\text {base }} & = & \text { Currently used release rate during shutdown, } \mathrm{Ci} / \mathrm{yr} / \mu \mathrm{Ci} / \mathrm{g} \\ \mathrm{CF} & = & \text { Capacity factor, fraction }\end{array}$

As discussed in Sections 3.3.3 and 4.3, the radionuclide release from various ventilation systems before treatment will be moved to input parameters with recommended default values. The above equations will be included in the input guidance with the recommended default values so the user can properly calculate these parameters.

\subsubsection{Adjustments for Anticipated Operational Occurrences}

The NRC staff noted that the adjustments made to the liquid effluents of $0.16 \mathrm{Ci}$ /year to account for anticipated operational occurrences is based on outdated information and should updated based on current experience. It is noted that the GALE-09 code was updated to use a much smaller value of $1.6 \times 10^{-4}$ $\mathrm{Ci} /$ year based on a survey of unexpected release from all the U.S. operating PWRs for up to five years between 2000 and 2008 (Geelhood, 2009). Altogether 320 reactor years of data were used to develop this. If desired, these data can be used to calculate a mean value as was used in GALE-09 or an upper bound (e.g. 95\% bounding with 95\% confidence). The majority of the unexpected releases from a nuclear power plant are water containing tritium. The adjustments for anticipated operation occurrences in GALE do not consider those tritium releases as the empirical tritium release parameters contain sufficient margin to account for unexpected release. The remaining unexpected release includes releases of noble gas, iodine and particulates from accidental venting, or liquid releases from small pipe breaks or accidental valve opening. The procedures in place at the plants have led to these events being minimized. However, since the unexpected release is much smaller than the total release and since they are mostly due to accidental breaks and opening of valves and vents, the unexpected release is not a function of the size of the plant.

Because of this, it is not anticipated that the unexpected releases from mPower ${ }^{\circledR}$ will be different from the operating PWRs given the similarity in the plant layout and the nature of these releases. Therefore, the updated adjusted to the liquid effluent should be applicable to the mPower ${ }^{\circledR}$ design. 


\subsubsection{Liquid and Gaseous Effluent Code Output Results and Presentation}

The NRC staff indicated that several outputs of GALE should be changed. These changes are easy to accomplish and include the following:

- The output should be presented in scientific notation rather than in decimal format

- GALE-86 outputs 0.00000 for any calculated value less than 1.0E-05. This threshold should be changed to $1.0 \mathrm{E}-06$

- The user should be given the option to display the output results in $\mathrm{Ci}$ or $\mathrm{TBq} .1 \mathrm{Ci}=3.7 \mathrm{e} 10$ $\mathrm{Bq}=0.037 \mathrm{TBq}$

- The output of C-14 should be presented as the quantity released as organic compounds and the quantity released as $\mathrm{C}-14$.

These changes, which are easy to accomplish, will improve the output of the current GALE codes as well as future versions applicable to reactors such as new PWR designs or iPWR designs. These changes will be further discussed in Section 4.4. The change regarding C-14 can be made if it is determined that there is relevant information to predict the release as organic compounds and as $\mathrm{CO}_{2}$ as discussed in Section 3.1.4 and 4.6.

\subsubsection{Code Structure and Operating Platform}

The NRC staff noted that there is a need to update the code's operating platform. A project is currently underway for the NRC Office of Research to create a standalone version of GALE that is easy to use. This standalone version is under development and will be ready in time to support the NRO review of the mPower ${ }^{\circledR}$ design.

The NRC staff also noted that the hard-coded parameters in GALE should be changed to be user inputs. These specific parameters are discussed in detail in Section 3.4.

\subsection{Issues Identified by Comparison of PWR and iPWR Designs}

PNNL performed a comparison between a reference PWR with 1970s vintage fuel and operations (Westinghouse 4-loop), a reference PWR with modern fuel and operations (Westinghouse 4-loop) and a reference iPWR (mPower $\left.{ }^{\circledR}\right)$. This comparison is shown in Section 2.0. As a result of this comparison, several issues were identified as having a possible impact on the nuclide releases from iPWR.

This section provides an analysis of each of the issues that was identified in the comparison of PWR and iPWR designs. Any issue that reveals a gap in the applicability of the GALE-86 codes will be further discussed in Section 4.0 along with a discussion of the work that would be required to fill that gap. 


\subsubsection{Thermal Power Level}

The most obvious difference between the PWR design and the iPWR design is the thermal power level. This issue had previously been identified by NRC staff. The scaling of the thermal power and other reactor parameters to determine primary and secondary coolant radionuclide concentrations was discussed in Section 3.1.1. The use of the thermal power to estimate the yearly tritium release was discussed in Section 3.1.1 and will be discussed further in Section 3.2.4.

\subsubsection{Capacity factor}

Because the mPower ${ }^{\circledR}$ reactor has been designed to have a 4 year cycle with one refueling outage, the anticipated capacity factor will be $95 \%$ compared to a $90 \%$ capacity factor that has been observed in the US fleet of PWRs for the past ten years and an $80 \%$ capacity factor that was observed in the 1970s. As discussed in Section 3.1.7, the plant capacity factor will be changed to be an input parameter rather than a fixed value. This change is discussed in Section 4.3.

\subsubsection{Coolant temperature}

The coolant inlet $\left(568^{\circ} \mathrm{F}\right)$ and outlet $\left(609^{\circ} \mathrm{F}\right)$ temperature for mPower ${ }^{\circledR}$ are bounded by the coolant inlet $\left(557.3^{\circ} \mathrm{F}\right)$ and outlet $\left(624.8^{\circ} \mathrm{F}\right)$ temperature for the reference PWR (inlet and outlet temperatures have not significantly changed between 1970 and today). Therefore, it is not expected that any enhanced diffusion of radionuclides from the fuel rods or other in-core components will occur. This further supports the conclusion in Section 3.1.2 that the tables of nuclide concentrations used in GALE-09 will be appropriate for iPWR designs once they are correctly adjusted as described in ANS-18.1 (1999).

\subsubsection{Coolant Chemistry}

Although much of the coolant chemistry for mPower has not yet been decided or not yet reported, it has been reported that there will be no soluble boron used to control reactivity. Typically, PWRs use soluble boron in the form of boric acid to control reactivity. The concentration of boron in the coolant is adjusted throughout the cycle to maintain optimum reactivity as the fuel burns out. In order to maintain a neutral $\mathrm{pH}$, a buffer solution of lithium hydroxide is also added to the coolant in concentrations proportional to the boric acid. To reduce tritium production, the lithium hydroxide is enriched in the isotope, Li-7, which has a much smaller cross section for tritium production than Li-6.

As discussed in Section 3.1.1, the total tritium release and the coolant tritium concentrations for iPWR designs where soluble boron is not used is most likely less than would be predicted using the values in GALE-86 or GALE-09 and the table in ANS-18.1 (1999), respectively. PNNL staff has extensive experience calculating the tritium concentration and release from PWRs. An update to GALE to calculate expected total tritium release and coolant concentration for reactor designs without soluble boron such as mPower ${ }^{\circledR}$ could be prepared. These changes are further discussed in Section 4.5. 


\subsubsection{Integral Steam Generator}

One difference noted in the comparison of PWR and iPWR designs is that the reference PWR has a Utube steam generator while the iPWR has an integralonce through steam generator. Since PWR designs vary and some have U-tube steam generators while others have once through steam generators, the GALE-86 code allows the user to specify if the reactor has a U-tube or once-through steam generator. The primary question is if the integral once-through steam generator will behave significantly differently than the typical once-through steam generators used in PWRs.

Although the integral steam generator is colocated within the containment with the reactor core, it is not particularly close to the active zone of the reactor core such that there will not be significant neutron radiation on the integral steam generator that would have the potential to cause enhanced permeation of nuclides from the primary to the secondary coolant. Fast neutron radiation is known to cause enhanced diffusion in materials, such as steel, as collision with iron and other atoms causes atom displacement. Other forms of radiation, such as gamma, alpha and beta that are given off by radioactive particles do not cause enhanced diffusion through steel as they do not cause atom displacement. As shown in the figure to the side, between the steam generator and the reactor core are the control rod drive mechanism and structural steel. The neutron transport code, MCNP (X-5 Monte Carlo Team, 2003), was used to determine the neutron flux at the steam generator location. A typical neutron flux spectrum at the top of a modern PWR was used. This flux should be very similar to what is experienced in mPower ${ }^{\circledR}$ as the fuel design and the coolant conditions are the same. The height of the control rod drive mechanism was assumed to be 20 feet and is modeled at water. This assumption is conservative as in reality, this volume is filled with water and control rods, and the control rods have a higher cross section for neutrons that water does. It was assumed that the thickness of the structural steel is 10 inches.

Using this simplified model, MCNP calculated that after the 20 feet of water, the fast neutron flux is reduced by a factor of $10^{54}$. MCNP calculated that

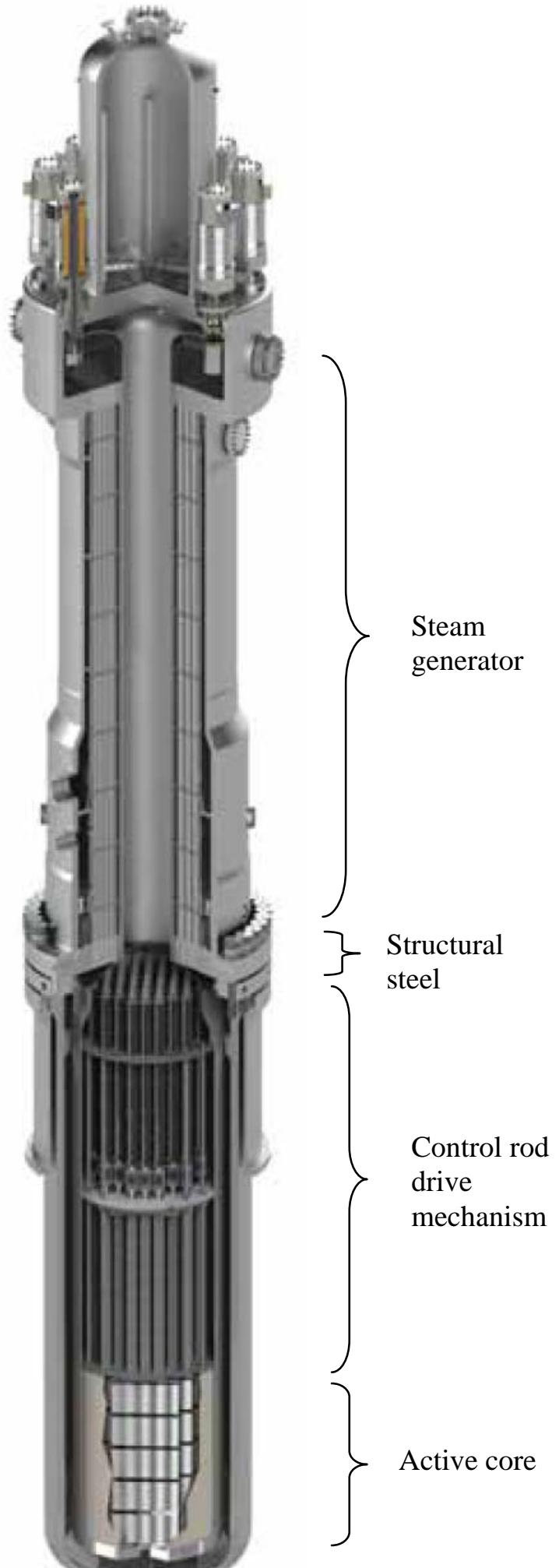

Control rod drive mechanism 
after the additional 10 inches of steel, the fast neutron flux is further reduced by a factor of $10^{4}$. The complete results from this calculation are shown in Table 3.2.

Based on these results, any neutron radiation at the elevation of the steam generator will be well below the level that would cause enhanced permeation. The tables in ANS-18.1 for secondary coolant concentration state that they are based on primary-to secondary leakage of $75 \mathrm{lbs} /$ day for both U-tube and once-through steam generators. This leakage term is likely bounding for the integral steam generator given that there is no reason to think there will be addition radiation enhanced permeation through the steam generator components.

Table 3.2. Calculated neutron flux at various locations in MPower® reactor

\begin{tabular}{lll}
\hline Location & $\begin{array}{l}\text { Total flux } \\
\mathbf{0}<\mathbf{E}<\mathbf{2 0} \mathbf{M e V}\end{array}$ & $\begin{array}{l}\text { Fast Flux } \\
\mathbf{E}>\mathbf{0 . 1} \mathbf{M e V}\end{array}$ \\
\hline Average core & $2.54 \times 10^{14} \mathrm{n} / \mathrm{cm}^{2} / \mathrm{s}$ & $1.80 \times 10^{14} \mathrm{n} / \mathrm{cm}^{2} / \mathrm{s}$ \\
Top of active core & $8.63 \times 10^{13} \mathrm{n} / \mathrm{cm}^{2} / \mathrm{s}$ & $6.11 \times 10^{13} \mathrm{n} / \mathrm{cm}^{2} / \mathrm{s}$ \\
$\begin{array}{l}\text { Top of control rod drive } \\
\text { mechanism }\end{array}$ & $1.12 \times 10^{-24} \mathrm{n} / \mathrm{cm}^{2} / \mathrm{s}$ & $4.66 \times 10^{-41} \mathrm{n} / \mathrm{cm}^{2} / \mathrm{s}$ \\
Bottom of steam generator & $7.83 \times 10^{-28} \mathrm{n} / \mathrm{cm}^{2} / \mathrm{s}$ & \\
\hline
\end{tabular}

\subsubsection{Fuel Enrichment}

One difference noted in the comparison of 1970s vintage PWR designs and modern PWR and iPWR designs is that the U-235 fuel enrichment in the 1970s vintage PWR designs (3\%) is quite a bit lower than for modern PWR and iPWR designs (5\%). There is a concern that the nuclide coolant concentration of fission product nuclides may have to be adjusted based on the fuel enrichment similar to how ANS-18.1 (1999) described adjustments for coolant volume and reactor power. This, however, is not the case.

The fuel enrichment in a nuclear fuel rod is similar to the gas in the tank of a car. The enrichment does not control the fission rate within the fuel. The fission rate is controlled with control rods, burnable poisons and soluble boron. Therefore, the total quantity of fission products produced in a year by a fuel rod with 3\% U-235 operating at $5 \mathrm{~kW} / \mathrm{ft}$ will be the same as the quantity of fission products produced in a year by a fuel rod with $5 \% \mathrm{U}-235$ operating at $5 \mathrm{~kW} / \mathrm{ft}$.

The reason the nuclear industry has begun using fuel with higher enrichment is to support higher burnup. Enrichment costs are less than fuel manufacturing costs and spent fuel storage costs, so economics have driven industry to higher burnup to reduce the number of fuel rods they have to buy and store.

The ratios of fission products from fresh fuel, medium burnup fuel, and high burnup fuel are slightly different as the fissions change from uranium fissions to plutonium fissions. However the fission yields from uranium and plutonium are similar and the differences are well within the uncertainty of the ANS18.1 (1999) tables and the GALE codes. 


\subsection{Issues Identified in GALE Sensitivity Study}

In 2009, PNNL conducted a sensitivity study on the hardwired parameters in the GALE codes. The result of this study was an assessment of which hardwired parameters had a significant impact on the calculation of the release of radionuclides of interest. The result of this study was used to guide the development of the latest developmental version of GALE, GALE-09.

The result of this study will also be used to identify any additional issues that could affect the applicability of GALE-86 to iPWRs. This section provides an analysis of each of the hardwired parameters that were issues that were identified in the GALE sensitivity study and if the values used are applicable to iPWR designs. Any issue that reveals a gap in the applicability of the GALE-86 codes will be further discussed in Section 4.0 along with a discussion of the work that would be required to fill that gap. Issues that have been previously identified and discussed in other sections will not be further discussed here.

\subsubsection{Capacity Factor}

Because the mPower ${ }^{\circledR}$ reactor has been designed to have a 4 year cycle with one refueling outage, the anticipated capacity factor will be $95 \%$ compared to a $90 \%$ capacity factor that has been observed in the US fleet of PWRs for the past ten years and an 80\% capacity factor that was observed in the 1970s. As discussed in Section 3.1.7, the plant capacity factor will be changed to be an input parameter rather than a fixed value. This change is discussed in Section 4.3.

\subsubsection{Nuclides in the Primary and Secondary Coolant}

The applicability of radionuclide concentration levels in the primary and secondary coolant to iPWR designs is discussed in Section 3.1.2, with a discussion of the scaling of these concentrations based on a number of reactor parameters in Section 3.1.1. It was determined that with the exception of tritium, these nuclide concentrations and the scaling equations are applicable to mPower and iPWR designs similar to this. Tritium release from mPower ${ }^{\circledR}$ and other iPWR designs that do not use soluble boron for reactivity control will have significantly lower tritium release than would be predicted by GALE-86 or GALE-09. This has been discussed in Sections 3.1.1 and 3.2.4. The proposed changes to account for this are further discussed in Section 4.5 .

\subsubsection{Radionuclide Release from Various Ventilation Systems before Treatment}

One of the most difficult items to determine is what the gaseous radionuclide release from various ventilation systems prior to treatment is. In GALE-86, these parameters have been determined by empirical parameters that are based on plant measurements. There are three principal radionuclide releases considered in GALE-86, including noble gases, iodine, and particulates.

Noble gas releases from the containment building are based on a leakage rate of $3 \%$ per day of primary coolant noble gas inventory. Releases from the auxiliary building are based on $160 \mathrm{lb} / \mathrm{day}$ primary coolant leakage. Releases from the turbine building are based on $1700 \mathrm{lb} / \mathrm{hr}$ steam leakage. 
Iodine release is presented in terms of $\mathrm{Ci} /$ year per $\mu \mathrm{Ci} / \mathrm{g}$ in the primary coolant. The values in GALE-86 are based on measurements made at plants (Chandrasekaren et al. 1985) and are shown in Table 3.3 for I-131 and I-133. These values should be applied for other iodine isotope,s as the permeation of all iodine isotopes is expected to by the same as discussed in Section 3.1.4 and 4.2. The differences will come from the concentration in the primary coolant of these nuclides. These values should also be adjusted for the capacity factor as discussed in Section 3.1.7.

Table 3.3. Iodine release to various buildings prior to treatment (currently used for I-131 and I-133)

\begin{tabular}{lll}
\hline Building & $\begin{array}{l}\text { Normal Operation } \\
\text { Ci/year per } \boldsymbol{\mu C i / g}\end{array}$ & $\begin{array}{l}\text { Shutdown } \\
\text { Ci/year per } \boldsymbol{\mu C i} / \mathbf{g}\end{array}$ \\
\hline Containment & 0.32 & 0 \\
Auxiliary & 0.68 & 2.5 \\
Refueling & 0.038 & 0.093 \\
Turbine & $3.8 \times 10^{3}$ & $4.2 \times 10^{2}$ \\
\hline
\end{tabular}

Particulate release is presented in terms of Ci/year. The values in GALE-86 are based on measurements made at plants (Chandrasekaren et al. 1985) and are shown in Table 3.4. These values are for the particulate releases that are currently considered in PWRGE. If other particulate releases were to be added, it would be necessary to gather the appropriate information for the desired nuclides. However, none of the additional nuclides discussed in Section 3.1.4 will be included in the particulate release.

Table 3.4. Particulate release to various buildings prior to treatment

\begin{tabular}{lllll}
\hline Nuclide & $\begin{array}{l}\text { Containment } \\
\text { Ci/year }\end{array}$ & $\begin{array}{l}\text { Auxiliary } \\
\text { Ci/year }\end{array}$ & $\begin{array}{l}\text { Fuel Pool } \\
\text { Ci/year }\end{array}$ & $\begin{array}{l}\text { Waste Gas } \\
\text { System } \\
\text { Ci/year }\end{array}$ \\
\hline Cr-51 & $9.2 \mathrm{E}-03$ & $3.2 \mathrm{E}-04$ & $1.8 \mathrm{E}-04$ & $1.4 \mathrm{E}-05$ \\
Mn-54 & $5.3 \mathrm{E}-03$ & $7.8 \mathrm{E}-05$ & $3.0 \mathrm{E}-04$ & $2.1 \mathrm{E}-06$ \\
Co-57 & $8.2 \mathrm{E}-04$ & $0.0 \mathrm{E}+00$ & $0.0 \mathrm{E}+00$ & $0.0 \mathrm{E}+00$ \\
Co-58 & $2.5 \mathrm{E}-02$ & $1.9 \mathrm{E}-03$ & $2.1 \mathrm{E}-02$ & $8.7 \mathrm{E}-06$ \\
Co-60 & $2.6 \mathrm{E}-03$ & $5.1 \mathrm{E}-04$ & $8.2 \mathrm{E}-03$ & $1.4 \mathrm{E}-05$ \\
Fe-59 & $2.7 \mathrm{E}-03$ & $5.0 \mathrm{E}-05$ & $0.0 \mathrm{E}+00$ & $1.8 \mathrm{E}-06$ \\
Sr-89 & $1.3 \mathrm{E}-02$ & $7.5 \mathrm{E}-04$ & $2.1 \mathrm{E}-03$ & $4.4 \mathrm{E}-05$ \\
Sr-90 & $5.2 \mathrm{E}-03$ & $2.9 \mathrm{E}-04$ & $8.0 \mathrm{E}-04$ & $1.7 \mathrm{E}-05$ \\
Zr-95 & $0.0 \mathrm{E}+00$ & $1.0 \mathrm{E}-03$ & $3.6 \mathrm{E}-06$ & $4.8 \mathrm{E}-06$ \\
Nb-95 & $3.0 \mathrm{E}-05$ & $2.4 \mathrm{E}-03$ & $3.7 \mathrm{E}-06$ \\
Ru-103 & $1.8 \mathrm{E}-03$ & $2.3 \mathrm{E}-05$ & $3.8 \mathrm{E}-05$ & $3.2 \mathrm{E}-06$ \\
Ru-106 & $1.6 \mathrm{E}-03$ & $6.0 \mathrm{E}-06$ & $6.9 \mathrm{E}-05$ & $2.7 \mathrm{E}-06$ \\
Sb-125 & $0.0 \mathrm{E}+00$ & $3.9 \mathrm{E}-06$ & $5.7 \mathrm{E}-05$ & $0.0 \mathrm{E}+00$ \\
Cs-134 & $0.0 \mathrm{E}+00$ & $5.4 \mathrm{E}-04$ & $1.7 \mathrm{E}-03$ & $3.3 \mathrm{E}-05$ \\
Cs-136 & $2.5 \mathrm{E}-03$ & $4.8 \mathrm{E}-05$ & $0.0 \mathrm{E}+00$ & $5.3 \mathrm{E}-06$ \\
Cs-137 & $3.2 \mathrm{E}-03$ & $7.2 \mathrm{E}-04$ & $2.7 \mathrm{E}-03$ & $7.7 \mathrm{E}-05$ \\
Ba-140 & $5.5 \mathrm{E}-03$ & $4.0 \mathrm{E}-04$ & $0.0 \mathrm{E}+00$ & $2.3 \mathrm{E}-05$ \\
Ce-141 & $0.0 \mathrm{E}+00$ & $2.6 \mathrm{E}-05$ & $4.4 \mathrm{E}-07$ & $2.2 \mathrm{E}-06$ \\
\hline
\end{tabular}


It is anticipated that these values for radionuclide concentration prior to treatment will be bounding for the mPower ${ }^{\circledR}$ design and other iPWR designs, but this cannot be confirmed since the values shown above are based on measurements at PWR plants (Chandrasekaren et al. 1985). PNNL recommends that these values should be changed from hardwired parameters to parameters that can be input into GALE with the values shown above being the default values. If requested, additional nuclides could be added to this input list with default values of zero. Additionally, the equations in Section 3.1.7 to adjust the radioiodine release rates will be included as user guidance with these default values. This change is further discussed in Section 4.3.

\subsection{4 lodine Release from the Main Condenser Exhaust}

The iodine release rate from the main condenser exhaust is hardwired in GALE-86 at $1.7 \times 10^{3} \mathrm{Ci} / \mathrm{yr}$ per $\mu \mathrm{Ci} / \mathrm{g}$ in the primary coolant. It was determined in the sensitivity study that biasing this value up and down by a factor of 10 had no impact on the release rates for the selected nuclides. This parameter only impacts the release rate of I-131 and I-133, and for the sample case, the fraction of I-131 released from the main condenser exhaust is not a significant fraction of the total I-131 released.

However, this parameter is empirically derived from plant measurements similar to the parameters in Section 3.3.3. It is recommended that this parameter should be changed from a hardwired value to a value that can be input into GALE with the value shown above being the default value. This change is further discussed in Section 4.3.

\subsubsection{Duration of Containment Air Cleanup, Percent of Air Treated, and Containment Purge Frequency}

The containment air cleanup system is modeled using several parameters. PWRGE assumes that the containment building is purged two times each year at shutdown. Additional purges can be specified in the input file. PWRGE assumes that the cleanup system will operate for 16 hours before purging, and will provide a decontamination factor (DF) of 100 for iodine on charcoal adsorbers and a DF of 100 for particulates on HEPA filters. Finally, PWRGE assumes a mixing efficiency of 70\%.

PNNL does not expect that these parameters will be significantly different for iPWR, but does note that these parameters are empirically derived and could change for both modern PWR operations and iPWR operations, particularly since mPower ${ }^{\circledR}$ will operate on 4-year cycles and most modern PWRs operate on 18-month cycles as opposed to the original PWR 12-month cycles.

It is recommended that these values should be changed from hardwired parameters to parameters that can be input into GALE with the values shown above being the default values. This change is further discussed in Section 4.3.

\subsubsection{Tritium Release}

Tritium release from mPower ${ }^{\circledR}$ and other iPWR designs that do not use soluble boron for reactivity control will have significantly lower tritium release than would be predicted by GALE-86 or GALE-09. This has been discussed in Sections 3.1.1 and 3.2.4. The proposed changes to account for this are further discussed in Section 4.5. 


\subsubsection{Carbon 14 Release}

C-14 release from GALE-86 is discussed in Section 3.1.4. If desired, GALE could be to allow for more fundamental C-14 release predictions and to extend the applicability of GALE to iPWR designs. The proposed changes to account for this are further discussed in Section 4.6.

\subsubsection{Argon 41 Release}

The GALE-86 does not perform any calculations for its output of Ar-41 release. The GALE-86 version of PWRGE used a value of $34 \mathrm{Ci} / \mathrm{yr}$ for Ar-41 release. Surveys were performed on the Ar-41 release from randomly selected reactors between the years 2000 and 2007 (Geelhood 2009). A total of 76 reactor years were surveyed, and a mean Ar-41 release value of $3.471 \pm 1.9904 \mathrm{Ci} / \mathrm{yr}$ was calculated with a 95\% confidence level. Based on this survey, Ar-41 release from PWR was changed in GALE-09 to the upper bound of the confidence level of the average value, or $6 \mathrm{Ci} / \mathrm{yr}$.

Ar-41 is formed by neutron activation of stable naturally occurring Ar-40 in the containment air surrounding the reactor vessel. The Ar-41 is released to the environment when the containment is vented or purged. Since mPower ${ }^{\circledR}$ and other iPWR designs will likely have a smaller volume of containment air than a PWR, the value of $6 \mathrm{Ci} /$ year will certainly be bounding. A calculation of Ar- 41 production in the containment air could be calculated if the neutron spectrum and flux outside the reactor core was well quantified, however, this is not the case. It is recommended that the GALE code use the constant value of $6 \mathrm{Ci} / \mathrm{yr}$ recently calculated for Ar-41 release from iPWR and concludes that it is bounding for any expected release.

\subsubsection{Nuclides in Detergent Waste}

The total liquid releases are computed in GALE-86 as the sum of plant operation liquid releases plus releases from detergent wastes. The nuclide concentration expected to be released from untreated detergent wastes in GALE-86 is shown in Table 3.5 (Chandrasekaren et al. 1985). The user has the option to specify if the plant has onsite laundry. In the case where the user specifies there is not onsite laundry, no additions are made to the final nuclide concentrations. In the case where the user specifies that there is an onsite laundry, the user should also specify a decontamination factor if the detergent waste is treated. GALE-86 reduces the concentrations shown in Table 3.5 by the input decontamination factor and adds these concentrations to the final values. These values are for the detergent wastes that are currently considered in PWRLE. If other nuclides were to be added, it would be necessary to gather the appropriate information for the desired nuclides. However, these nuclides are those that have been determined to be present in the largest quantities in detergent wastes and none of the additional nuclides discussed in Section 3.1.4 are planned to be included in the particulate release. 
Table 3.5. Annual release of radioactive materials in untreated detergent waste

\begin{tabular}{ll}
\hline Nuclide & Ci/year \\
\hline P-32 & $1.8 \mathrm{E}-04$ \\
Cr-41 & $4.7 \mathrm{E}-03$ \\
Mn-54 & $3.8 \mathrm{E}-03$ \\
Fe-55 & $7.2 \mathrm{E}-03$ \\
Fe-59 & $2.2 \mathrm{E}-03$ \\
Co-58 & $7.9 \mathrm{E}-03$ \\
Co-60 & $1.4 \mathrm{E}-02$ \\
Ni-63 & $1.7 \mathrm{E}-03$ \\
Sr-89 & $8.8 \mathrm{E}-05$ \\
Sr-90 & $1.3 \mathrm{E}-05$ \\
Y-91 & $8.4 \mathrm{E}-05$ \\
Zr-95 & $1.1 \mathrm{E}-03$ \\
Nb-95 & $1.9 \mathrm{E}-03$ \\
Mo-99 & $6.0 \mathrm{E}-05$ \\
Ru-103 & $2.9 \mathrm{E}-04$ \\
Ru-106 & $8.9 \mathrm{E}-03$ \\
Ag-110m & $1.2 \mathrm{E}-03$ \\
Sb-124 & $4.3 \mathrm{E}-04$ \\
I-131 & $1.6 \mathrm{E}-03$ \\
Cs-134 & $1.1 \mathrm{E}-02$ \\
Cs-136 & $3.7 \mathrm{E}-04$ \\
Cs-137 & $1.6 \mathrm{E}-02$ \\
Ba-140 & $9.1 \mathrm{E}-04$ \\
Ce-141 & $2.3 \mathrm{E}-04$ \\
Ce-144 & $3.9 \mathrm{E}-03$
\end{tabular}

PNNL does not have information to assess if there will be differences in the annual releases of radioactive materials in untreated detergent waste between iPWR reactors and PWR reactors. However, the 4-year cycle of mPower ${ }^{\circledR}$ means there are less workers in the fuel area contaminating clothes. Additionally, the values shown in Table 3.5 are based on a survey of four plants in the 1970s. It is expected that due to modern best practices and ALARA, that modern plants will have significantly lower concentrations of nuclides in the detergent wastes.

It is recommended that these values should be changed from hardwired parameters to parameters that can be input into GALE with the values shown above being the default values. This change is further discussed in Section 4.3. Additionally, if requested additional nuclides could be added to this input list with default values of zero.

\subsubsection{Decontamination Factors for Demineralizers, Evaporators and Reverse Osmosis Units}

For all the liquid radwaste systems in GALE-86, except the condensate demineralizer and the primary coolant demineralizer, the user is required to input the expected decontamination factor (DF). For the condensate demineralizer, GALE-86 assumes decontamination factors of 2 for cesium and rubidium and 
10 for all other nuclides. For the primary coolant demineralizer, GALE-86 assumes decontamination factors of 2 for cesium and rubidium, 100 for anions, and 50 for other nuclides. The DF of 50 for other nuclides was changed to 10 in GALE-09. Following this change, the DFs in GALE math those in ANS55.6-1993 R 2007 assuming that the condensate demineralizer is a boron recycle system and the primary coolant demineralizer is a mixed bed purification system.

The demineralizers may be different for the mPower ${ }^{\circledR}$ design or for other iPWRs. It is recommended that these values should be changed from hardwired parameters to parameters that can be input into GALE with the values shown above being the default values. Additionally, it is recommended that the user input an appropriate value for a DF as provided in ANS-55.6-1993 R 2007. This change is further discussed in Section 4.3.

\subsubsection{Frequency and Extent of Unplanned Release}

The GALE-86 code uses a value of $0.16 \mathrm{Ci} /$ year to modify the final liquid releases to account for unplanned releases. This value was updated in the GALE-09 code to use a value of $1.6 \times 10^{-4} \mathrm{Ci} /$ year to modify the final liquid releases to account for unplanned releases. As discussed in Section 3.1.8, this value is based on a survey of unexpected release from all the U.S. operating PWRs for up to five years between 2000 and 2008. Altogether 320 reactor years of data were used to develop this. PNNL can use these data to calculate a mean value as was used in GALE-09 or an upper bound (e.g. 95\% bounding with 95\% confidence). It is not anticipated that the unexpected releases from mPower ${ }^{\circledR}$ will be different from the operating PWRs given the similarity in the plant layout. Therefore, the updated adjusted to the liquid effluent should be applicable to the mPower ${ }^{\circledR}$ design.

\subsection{Issues Identified from Main Bases in NUREG-0017}

The PWR GALE description document (NUREG-0017) identifies number of parameters that are built into the PWR-GALE codes. Each of these parameters is examined in this section in order to determine if the built in value is applicable to iPWR designs, or if the parameter should be changed from a built-in parameters to an input parameter with a recommended default value.

This section provides an analysis of each of the built-in parameters that were identified in NUREG0017. Any issue that reveals a gap in the applicability of the GALE-86 codes will be further discussed in Section 4.0 along with a discussion of the work that would be required to fill that gap. Issues that have been previously identified and discussed in other sections will not be further discussed here.

\subsubsection{Capacity Factor}

Because the mPower ${ }^{\circledR}$ reactor has been designed to have a 4-year cycle with one refueling outage, the anticipated capacity factor will be $95 \%$ compared to a $90 \%$ capacity factor that has been observed in the U.S. fleet of PWRs for the past ten years and an 80\% capacity factor that was observed in the 1970s. As discussed in Section 3.1.7, the plant capacity factor will be changed to be an input parameter rather than a fixed value. This change is discussed in Section 4.3. 


\subsubsection{Radionuclide Concentrations in the Primary Coolant, Secondary Coolant, and Main Steam}

The applicability of radionuclide concentration levels in the primary and secondary coolant to iPWR designs is discussed in Section 3.1.2, with a discussion of the scaling of these concentrations based on a number of reactor parameters in Section 3.1.1. It was determined that with the exception of tritium, these nuclide concentrations and the scaling equations are applicable to mPower and iPWR designs similar to mPower ${ }^{\circledR}$. Tritium release from mPower ${ }^{\circledR}$ and other iPWR designs that do not use soluble boron for reactivity control will have significantly lower tritium release than would be predicted by GALE-86 or GALE-09, as discussed in Sections 3.1.1 and 3.2.4. The proposed changes to account for this are further discussed in Section 4.5 .

\subsubsection{Radioiodine Releases from Building Ventilation Systems Prior to Treatment}

The radioiodine releases from building ventilation systems prior to treatment are discussed in Section 3.3.3. It was decided that these parameters are empirically based and there is no clear basis for these parameters as they relate to mPower ${ }^{\circledR}$ or other iPWR designs. Therefore, it is recommended that these parameters be moved to input variables with the current values as the default. This recommendation is discussed in Section 4.3.

\subsubsection{Radioactive Particulate Releases from Building Ventilation Systems Prior to Treatment}

The radioactive particulate releases from building ventilation systems prior to treatment are discussed in Section 3.3.3. It was decided that these parameters are empirically based and there is no clear basis for these parameters as they relate to mPower ${ }^{\circledR}$ or other iPWR designs. Therefore, it is recommended that these parameters be moved to input variables with the current values as the default. This recommendation is discussed in Section 4.3.

\subsubsection{Nobel Gas Releases from Building Ventilation Systems}

The noble gas releases from building ventilation systems prior to treatment are discussed in Section 3.3.3. It was decided that these parameters are empirically based and there is no clear basis for these parameters as they relate to mPower ${ }^{\circledR}$ or other iPWR designs. Therefore, it is recommended that these parameters be moved to input variables with the current values as the default. This recommendation is discussed in Section 4.3.

\subsubsection{Containment Building Purge Frequency}

The containment building purge frequency is discussed in Section 3.3.5. It was decided that this parameter is based on a 1-year cycle and may not be applicable to modern 18-month PWR cycles or to mPower ${ }^{\circledR} 4$-year cycles. Therefore, it is recommended that this parameter be moved to an input variable with the current value as the default. This recommendation is discussed in Section 4.3. 


\subsubsection{Primary System Volumes Degassed per Year}

GALE-86 assumes that there will be two primary system volume degassed during each cold shutdown in addition to any volumes degassed due to continuous stripping. The parameters for the continuous stripping, if any occurs, is specified by the user in the input deck. The mPower ${ }^{\circledR}$ design is anticipated to only go into cold shutdown every 4 years. Therefore, the value in GALE-86 of two volumes per year at shutdown will be significantly greater than what is expected for mPower ${ }^{\circledR}$. Therefore, it is recommended that this parameter be moved to an input variable with the current value as the default. This recommendation is discussed in Section 4.3.

\subsubsection{Steam Generator Partition Coefficient}

In GALE-86 the steam generator partition for iodine and nonvolatiles are hardwired into the code. The values that are assumed are shown in Table 3.6. NUREG-0017 does not provide a clear basis behind the values selected. The mPower ${ }^{\circledR}$ design has a once-through steam generator and, because there will be no blowdown, an appropriate partition coefficient would be 1.0 as stated in Table 3.6. Nevertheless, since there is no clear basis for the U-tube steam generator partition coefficient and another iPWR design may used a U-tube steam generator, it is recommended that these parameters be moved to input variables with the current values as the default. This recommendation is discussed in Section 4.3.

Table 3.6. Steam Generator Partition Coefficient

\begin{tabular}{lll}
\hline Nuclide & $\begin{array}{l}\text { Once-through steam generator } \\
\text { partition coefficient }\end{array}$ & $\begin{array}{l}\text { U-tube steam generator } \\
\text { partition coefficient }\end{array}$ \\
\hline Iodine & 1.0 & 0.01 \\
Nonvolatiles & 1.0 & 0.005 \\
\hline
\end{tabular}

\subsubsection{Radioiodine Releases from the Main Condenser Air Ejector Exhaust Prior to Treatment}

The radioiodine release from the main condenser air ejector exhaust prior to treatment is discussed in Section 3.3.4. It was decided that this parameter is empirically based and there is no clear basis for this parameter as it relates to mPower ${ }^{\circledR}$ or other iPWR designs. Therefore, it is recommended that this parameter be moved to an input variable with the current value as the default. This recommendation is discussed in Section 4.3.

\subsubsection{Containment Internal Cleanup System}

The containment internal cleanup system parameters are discussed in Section 3.3.5. It was decided that these parameters are empirically based and there is no clear basis for these parameters as they relate to mPower ${ }^{\circledR}$ of other iPWR designs. Therefore, it is recommended that these parameters be moved to input variables with the current values as the default. This recommendation is discussed in Section 4.3. 


\subsubsection{Detergent Wastes}

The radionuclides in the detergent waste are discussed in Section 3.3.9. It was decided that these parameters are empirically based on measurements from the 1970's and there is no clear basis for these parameters as they relates to modern operations of PWR or iPWR designs. Therefore, it is recommended that these parameters be moved to input variables with the current values as the default. This recommendation is discussed in Section 4.3.

\subsubsection{Tritium Releases}

Tritium release from mPower ${ }^{\circledR}$ and other iPWR designs that do not use soluble boron for reactivity control will have significantly lower tritium release than would be predicted by GALE-86 or GALE-09. This has been discussed in Sections 3.1.1 and 3.2.4. The proposed changes to account for this are further discussed in Section 4.5.

\subsubsection{Argon 41 Releases}

The Ar-41 release in GALE-86 and the update to this value in GALE-09 are discussed in Section 3.3.8. No further changes beyond those made in GALE-09 are recommended to extend the applicability of GALE to iPWR designs for Ar-41 releases.

\subsubsection{Carbon 14 Releases}

C-14 release in GALE-86 and the update to this value made in GALE-09 are discussed in Section 3.1.4. It is recommended changes be made to GALE to allow for more accurate C-14 release predictions and to extend the applicability of GALE to iPWR designs. The proposed changes to account for this are further discussed in Section 4.6.

\subsubsection{Decontamination Factor for Condensate Demineralizers}

The decontamination factors for condensate demineralizer are discussed in Section 3.3.10. It was decided for GALE-09 that these parameters should be based on the assumption that the condensate demineralizer will be a boron recycle system and the DFs are taken from ANS-55.6-1993. Since mPower ${ }^{\circledR}$ will not use soluble boron, it will likely use a different type of demineralizer for the condensate demineralizer. Therefore, it is recommended that these parameters be moved to input variables with the current values as the default and the table from ANS-55.6-1993 as a reference. This recommendation is discussed in Section 4.3.

\subsubsection{Primary Coolant Purification System Demineralizers}

The decontamination factors for primary coolant purification system demineralizer are discussed in Section 3.3.10. It was decided that these parameters are based on the assumption that the primary coolant system demineralizer will be a mixed bed purification system and the DFs are taken from ANS-55.61993. Since mPower ${ }^{\circledR}$ may use a different type of demineralizer for the primary coolant system demineralizer, this may not be applicable. Therefore, it is recommended that these parameters be moved 
to input variables with the current values as the default and the table from ANS-55.6-1993 as a reference. This recommendation is discussed in Section 4.3.

\subsubsection{Releases of Radioactive Material in Liquid Wastes from Turbine Building Floor Drain}

The GALE-86 code assumes a value of 7200 gal/day at main steam activity for the release of radioactive material in liquid wastes from the turbine building floor drain. There is no basis given for this value in NUREG-0017. Therefore it is not possible to assess the applicability of this values to mPower ${ }^{\circledR}$ or other iPWR designs. It is recommended that this parameter be moved to an input variable with the current value as the default. This recommendation is discussed in Section 4.3.

\subsubsection{Regeneration of Condensate Demineralizers}

In GALE-86 the flow rates and concentrations of radioactive materials routed to the liquid radwaste treatment system from the chemical regeneration of the condensate demineralizers are based on the following parameters:

1. Liquid flow to the demineralizer is based on the radioactivity of the main steam of the fraction of radioactivity which does not bypass the condensate demineralizer if there is pumped forward flow. The steam generator blowdown radioactivity is added to the condensate radioactivity if the blowdown is processed through the condensate demineralizer.

2. All radionuclides removed from the secondary coolant by the demineralizer resins are removed from the resins during chemical regeneration. The radioactivity in the regenerant wastes is adjusted for radionuclide decay during demineralizer operation.

The mPower ${ }^{\circledR}$ design uses a once-through steam generator and therefore there will be any steam generator blowdown to add to the demineralizer. The processes described here are reasonable and it is recommended that they be retained in the GALE code and will be applicable to iPWR designs.

\subsubsection{Adjustments to Liquid Radwaste Source Terms for Anticipated Operational Occurrences (AOO)}

The GALE-86 code uses a value of $0.16 \mathrm{Ci} /$ year to modify the final liquid releases to account for unplanned releases. This value was updated in the GALE-09 code to use a value of $1.6 \times 10^{-4} \mathrm{Ci} /$ year to modify the final liquid releases to account for unplanned releases. As discussed in Section 3.1.8, this value is based on a survey of unexpected release from all the U.S. operating PWRs for up to five years between 2000 and 2008. Altogether 320 reactor years of data were used to develop this. These data can use these data to calculate a mean value as was used in GALE-09 or an upper bound (e.g. 95\% bounding with $95 \%$ confidence). It is not anticipated that the unexpected releases from mPower ${ }^{\circledR}$ will be different from the operating PWRs given the similarity in the plant layout. Therefore, the updated adjusted to the liquid effluent should be applicable to the mPower ${ }^{\circledR}$ design. 



\subsection{Areas GALE-86 is not applicable to iPWR}

This section describes the areas of GALE-86 that were identified in Section 3 to not be applicable to iPWR designs. A proposal of work that can be performed to address the deficiencies in each of these areas is given in the sections below. The first recommendation is to use GALE-09. GALE-09 has been designed to reflect modern PWR design and operations which is the basis for iPWRs. All the remaining changes can be made to the current versions of the GALE-09 codes. It is not necessary to create a separate iPWR version of GALE. Rather, with the proposed modifications, the PWR GALE codes can be applicable to iPWR designs with the proper use input specified.

\subsection{Changes Made to Reflect Modern PWR Design and Operations}

PNNL has been performing work for the NRC Office of Research to recommend changes to the GALE-86 code to make them more applicable to modern reactor designs and operations. Since this work began, two versions of GALE have been created, GALE-08 and GALE-09. The following sections list the changes made to the PWR codes for of each of these versions.

GALE-08

- Equations used to adjust the nuclide concentrations from those given for the reference reactor were changed to match the equations and parameters given in ANS-18.1 (1999).

- The quantities of various radionuclides in the primary and secondary coolant were changed to match those in the tables shown in ANS-18.1 (1999).

GALE-09

- Capacity factor was increased from $80 \%$ to $90 \%$.

- Tritium release rate was decreased from $0.4 \mathrm{Ci} / \mathrm{yr} / \mathrm{MWth}$ to $0.27 \mathrm{Ci} / \mathrm{yr} / \mathrm{MWth}$.

- $\mathrm{Ar}-41$ release rate was decreased from $34 \mathrm{Ci} / \mathrm{yr}$ to $6 \mathrm{Ci} / \mathrm{yr}$.

- $\mathrm{C}-14$ release rate was decreased from $7.3 \mathrm{Ci} / \mathrm{yr}$ to $5.9 \mathrm{Ci} / \mathrm{yr}$.

- The unexpected release rate was decreased from $0.16 \mathrm{Ci} / \mathrm{yr}$ to $1.6 \times 10^{-4} \mathrm{Ci} / \mathrm{yr}$.

- The PWR condensate demineralizer decontamination factor for other nuclides was changed from 50 to 10 .

The changes proposed in the following sections are made based on GALE-09, which contains all the above changes. No work further effort is required to obtain GALE-09 and the revised draft NUREG0017 documentation as this work has already been performed for the NRC Office of Research.

\subsection{Addition of New Nuclides to GALE Output}

The radionuclides, I-132, I-134, I-135, and Tc-99m are currently already considered in PWRLE. These radionuclides are not included in every code output, as the current code only reports nuclides with concentration greater than 1E-05 Ci/yr. I-132, I-134, and I-135 will be added to the PWRGE. The iodine release parameters to various buildings will be the same for all iodine isotopes, so all that is required is to add the coolant concentrations of I-132, I-134, and I-135, which is given in ANS-18.1 (1999) and the decay constants which are given in the PWRLE nuclear data file. Tc-99m will not be added as a 
particulate release in PWRGE, as there is no data or evidence for a significant quantity of Tc-99m released as a particulate in the gaseous waste stream.

The concentrations of I-129 and Tc-99 in the primary coolant are not given in ANS-18.1 (1999) because these nuclides have half-lives on the order of hundreds of thousands to millions of years. In order to determine what the concentrations of I-129 and Tc-99 are in the primary coolant, the SCALE and ORIGEN codes will be used to calculate the steady-state ratios of I-129 and Tc-99 are due to fission of $\mathrm{UO}_{2}$ fuel and the neutron activation and radioactive decay. These ratios will be used to calculate the concentrations of I-129 and Tc-99 relative to other similar fission product isotopes that are included in ANS-18.1 (1999). The same fraction of I-129 and Tc-99 should leak from the primary coolant to the secondary coolant as the other I and Tc isotopes. Therefore the concentration of I-129 and Tc-99 in the secondary coolant will be calculated based on the ratio of other I and Tc isotopes in the primary and secondary coolant given in ANS-18.1 (1999). Once these coolant concentrations are calculated, the same procedure as discussed above will be used to add I-129 and Tc-99 to PWRLE and to add I-129 to PWRGE.

The release of F-18 would be significantly more difficult to add to GALE than some of the other nuclides. The nuclear data is not included in the nuclear data file in GALE. Additionally, the concentration of this nuclide in the primary and secondary coolant is not given in ANS-18.1. Production rates for F-18 have been given in the literature and could be calculated. In general, it is assumed that F-18 is formed by the following proton reaction:

${ }_{8}^{18} \mathrm{O}+{ }_{1}^{1} \mathrm{p} \rightarrow\left[{ }_{9}^{19} \mathrm{~F}\right] \rightarrow{ }_{9}^{18} \mathrm{~F}+{ }_{0}^{1} \mathrm{n}+\mathrm{Q}$

F-18 produced in the coolant will rapidly combine with LiF to form a particulate. Any water that leaks from the primary coolant to the containment building had the potential to be released as a particulate during the containment building purge. It would be possible to add the release of F-18 to PWRGE by calculating the steady-state coolant concentration of F-18, assuming some leak rate to the containment building, and applying the existing purge frequencies and cleanup steps to F-18. It is likely that this will result in negligible release of F-18 due to its very short half life, but it could be done. However, the presence and estimated concentrations of F-18 may be used for other purposes by the staff and applicants, such as in demonstrating compliance with technical specifications on RCS coolant leakage rate of 1 $\mathrm{gal} / \mathrm{min}$ by radiation monitoring of containment atmospheres.

\subsection{Hardwired Parameters in GALE-09 Changed to User Input}

The parameters that have been identified in Section 3 as needing to change from hardwired parameters to user input are listed in Table 4.1. PNNL recommends that a new input file called parameters.dat be created. The GALE codes will be modified to attempt to locate this file in the working directory. If this file is not present, the GALE codes will proceed using the default values that are currently hardwired in GALE-09. If this file is present, the values set by the user in this file will supersede the default values. This will allow the user the flexibility to change any of the parameters to more effectively be able to model the mPower ${ }^{\circledR}$ reactor or any other PWR. The format of parameters.dat will be namelist input with comments so the user has a clear understanding of the parameters and their values. All the parameters in Table 4.1 will be included in the parameters.dat file. 
Table 4.1. Hardwired parameters in PWR GALE codes that should be changed to user input

\begin{tabular}{|c|c|c|}
\hline Parameter & Value in GALE-09 & Applicability to iPWR \\
\hline Capacity Factor & $90 \%$ & mPower ${ }^{\circledR}$ could be up to $95 \%$ \\
\hline $\begin{array}{l}\text { Nobel gas release from the } \\
\text { containment building }\end{array}$ & $\begin{array}{l}3 \% \text { per day of primary coolant } \\
\text { noble gas inventory }\end{array}$ & $\begin{array}{l}\text { Unknown, based on } \\
\text { measurements at PWRs }\end{array}$ \\
\hline $\begin{array}{l}\text { Nobel gas release from the } \\
\text { auxiliary building }\end{array}$ & $\begin{array}{l}160 \text { lb/day primary coolant } \\
\text { leakage }\end{array}$ & $\begin{array}{l}\text { Unknown, based on } \\
\text { measurements at PWRs }\end{array}$ \\
\hline $\begin{array}{l}\text { Noble gas release from the } \\
\text { turbine building }\end{array}$ & $1700 \mathrm{lb} / \mathrm{hr}$ steam leakage & $\begin{array}{l}\text { Unknown, based on } \\
\text { measurements at PWRs }\end{array}$ \\
\hline $\begin{array}{l}\text { Iodine release to building } \\
\text { ventilation prior to treatment }\end{array}$ & Table 3.3 & $\begin{array}{l}\text { Unknown, based on } \\
\text { measurements at PWRs } \\
\text { Input values should be adjusted } \\
\text { for capacity factor }\end{array}$ \\
\hline $\begin{array}{l}\text { Particulate release to building } \\
\text { ventilation prior to treatment }\end{array}$ & Table 3.4 & $\begin{array}{l}\text { Unknown, based on } \\
\text { measurements at PWRs }\end{array}$ \\
\hline $\begin{array}{l}\text { Iodine release rate from the main } \\
\text { condenser exhaust }\end{array}$ & $\begin{array}{l}1.7 \times 10^{3} \mathrm{Ci} / \mathrm{yr} \text { per } \mu \mathrm{Ci} / \mathrm{g} \text { in the } \\
\text { primary coolant }\end{array}$ & $\begin{array}{l}\text { Unknown, based on } \\
\text { measurements at PWRs }\end{array}$ \\
\hline Containment building purges & $\begin{array}{l}2 \text { per year plus additional purges } \\
\text { specified in input }\end{array}$ & $\begin{array}{l}\text { Based on 1-year cycles. } \\
\text { mPower }{ }^{\circledR} \text { is } 4 \text {-year cycles. } \\
\text { Change to require all purges to } \\
\text { be input }\end{array}$ \\
\hline $\begin{array}{l}\text { Duration of containment } \\
\text { building cleanup prior to purging }\end{array}$ & 16 hours & $\begin{array}{l}\text { Unknown, based on } \\
\text { measurements at PWRs }\end{array}$ \\
\hline $\begin{array}{l}\text { DF for iodine in containment } \\
\text { building cleanup }\end{array}$ & 100 & $\begin{array}{l}\text { Should be applicable since } \\
\text { charcoal is the same }\end{array}$ \\
\hline $\begin{array}{l}\text { DF for particulates in } \\
\text { containment building cleanup }\end{array}$ & 100 & $\begin{array}{l}\text { Should be applicable since } \\
\text { HEPA is the same }\end{array}$ \\
\hline $\begin{array}{l}\text { Containment air mixing } \\
\text { efficiency }\end{array}$ & $70 \%$ & Should be applicable \\
\hline DF for condensate demineralizer & $\begin{array}{l}10 \text { for anions } \\
2 \text { for } \mathrm{Cs} \text { and } \mathrm{Rb} \\
10 \text { for other nuclides }\end{array}$ & $\begin{array}{l}\text { Assumes boron recycle system } \\
\text { from ANS-55.6-1993. Will be } \\
\text { different for mPower }{ }^{\circledR}\end{array}$ \\
\hline $\begin{array}{l}\text { DF for primary coolant } \\
\text { demineralizer }\end{array}$ & $\begin{array}{l}100 \text { for anions } \\
2 \text { for Cs and } \mathrm{Rb} \\
10 \text { for other nuclides }\end{array}$ & $\begin{array}{l}\text { Assumes mixed bed purification } \\
\text { system from ANS-55.6-1993. } \\
\text { May be different for mPower }{ }^{\circledR}\end{array}$ \\
\hline Nuclides in detergent waste & Table 3.5 & $\begin{array}{l}\text { Unknown, based on } \\
\text { measurements at PWRs }\end{array}$ \\
\hline $\begin{array}{l}\text { Primary system volumes } \\
\text { degassed per year }\end{array}$ & 2 per year at cold shutdown & $\begin{array}{l}\text { Based on 1-year cycles. } \\
\text { mPower® has } 4 \text {-year cycles and } \\
\text { will likely not have } 1 \text { cold } \\
\text { shutdown per year. }\end{array}$ \\
\hline $\begin{array}{l}\text { Steam generator partition } \\
\text { coefficient }\end{array}$ & Table 3.6 & $\begin{array}{l}\text { mPower }{ }^{\circledR} \text { has a once-through } \\
\text { steam generator and PCs are } \\
\text { valid for this. U-tube PCs may } \\
\text { change for iPWR design with U- } \\
\text { tube steam generator. }\end{array}$ \\
\hline
\end{tabular}




\begin{tabular}{lll}
\hline Parameter & Value in GALE-09 & Applicability to iPWR \\
\hline $\begin{array}{l}\text { Release of radioactive material } \\
\text { in liquid wastes from the turbine } \\
\text { building floor drain }\end{array}$ & $\begin{array}{l}\text { 7200 gal/day at main steam } \\
\text { activity }\end{array}$ & $\begin{array}{l}\text { Unknown. No basis given for } \\
\text { value. }\end{array}$ \\
\hline
\end{tabular}

\subsection{Changes to GALE Input and Output Format}

The outputs of nuclide concentrations in PWRGE are currently presented in scientific notation. No changes need to be made to accommodate this request for PWRGE. The outputs of nuclide concentration in PWRLE are presented in a mixture of scientific and decimal notation. The output is controlled by three format statements shown below:

9003 FORMAT(1X, A2 , I3, A1, 2X, 1PE9. 2, 2(2X, E9. 2, 2X) , ๑P, 7 (1X, F9. 5, 1X) , F10.5)

9004 FORMAT (1X, "ALL OTHERS", 9X, 1PE9.2, 4X, E9.2, OP, 2X, 6(1X, F9.5, 1X) , 3X, 1 "๑. $0000 \odot ", 1 \mathrm{X}, \mathrm{F} 10.5)$

9005 FORMAT(" TOTAL"/," (EXCEPT TRITIUM) ",1PE9.2, 4X, E9.2, OP, 2X, $17(1 \mathrm{X}, \mathrm{F} 9.5,1 \mathrm{X}), \mathrm{F} 10.5)$

The "F9.5" and "F10.5" specifiers are causing the output to be in decimal notation. These can be changed to "E9.2" or "E10.2" to change the output to be in scientific notation.

The outputs of nuclide concentration in PWRLE are reported as 0.00000 for any calculated value less than $1.0 \mathrm{E}-05 \mathrm{Ci} / \mathrm{yr}$. When the change to output in scientific notation is made, this will not be the case. Any value that PWRLE calculates will be reported. However, PWRLE has a cutoff level that it does not report the nuclide concentration for a nuclide if the total concentration of that nuclide is less than 0.00001 $\mathrm{Ci} / \mathrm{yr}$. This cutoff level is controlled by the following statement.

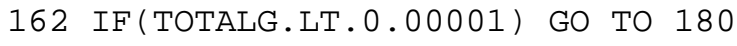

If the argument in the above "if" statement is changed to 0.000001, then PWRLE will report nuclide concentrations for all nuclides who's total release is greater than $1.0 \mathrm{E}-6 \mathrm{Ci} / \mathrm{yr}$.

The outputs of nuclide concentrations in PWRGE are reported as 0 if the calculate concentration is less than $1 \mathrm{Ci} / \mathrm{yr}$ for noble gas and less than $0.0001 \mathrm{Ci} / \mathrm{yr}$ for iodine. These limits are controlled by the following statements

TEST $=1.0$

$360 \quad \mathrm{TEST}=0.0001$

These statements can be used to control the lowest bound concentration that PWRGE reports for release of noble gas and iodine.

The outputs of PWRGE and PWRLE are in Ci/yr. These outputs can be changed to TBq by adding a new user input variable to select output in $\mathrm{Ci} / \mathrm{yr}$ or TBq/yr. An "if" statement will then be added to all the applicable "write" statements to write out the appropriate variables times 0.037 if output in $\mathrm{TBq} / \mathrm{yr}$ is selected.

For both the PWRGE and PWRLE it is recommended that each code be also updated to create two new output files that contain at the estimated total annual gaseous and liquid release rates for each 
radionuclide. These files should have consistent structures as well as format for radionuclide names. This update will facilitate the transfer of the GALE results to other analysis programs and platforms.

\subsection{Tritium Production and Release from Plants without Soluble Boron}

In order to calculate the concentration of tritium in the coolant of a plant without soluble boron such as mPower ${ }^{\circledR}$ a model of the reactor will be constructed using the neutronics code, WIMS8A. This code will calculate the source of tritium from the coolant from neutron reactions with lithium, deuterium, and oxygen. It will also calculate tritium production and release from various in-core components such as neutron secondary source rod(s), non-integral burnable absorber rods, and fuel rods.

In general it is assumed that all tritium that is produced will be released to the environment via gas or liquid pathways except what has decayed between the time the tritium was produced and the time the liquid or gas containing the tritium is released. Since the half-life of tritium is 12.3 years, the amount released is typically around $95 \%$ of the produced. In order to be conservative, GALE-09 will be modified to assume all the tritium produced in an iPWR will be released with $90 \%$ being released as liquid and $10 \%$ being released as gas. A new input variable will be added for the user to state if soluble boron is used in the reactor design. If it is used, the code will use the current tritium release calculations. If it is not used, the code will use the new tritium release calculation.

\subsection{Carbon-14 Production and Release}

The GALE-86 and GALE-09 calculations of C-14 release in PWRGE are based on empirical measurements made at plants and are not a function of plant size. A recent EPRI report (Kim 2010) provides a methodology for calculating the production of C-14 in the reactor coolant system and the release which is predominantly though gaseous pathways. The EPRI report also provides recommendations for the fraction of gaseous $\mathrm{C}-14$ released as organic and as $\mathrm{CO}_{2}$.

Two new input variables should be added to GALE. The first is the mass of the primary coolant in the active core. The second is an integer variable to specify if there is a recombiner in the gas treatment system.

The EPRI report described method to calculate PWR site-specific C-14 source term, based on knowledge of the neutron flux distributions and coolant mass in the active core during the fuel cycle. Since it the neutron flux distributions for an individual plant are not readily available and since these do not change much from plant to plant, the EPRI method was simplified to assume standard values of neutron flux in PWRs for inclusion in PWRGE. Additionally, the EPRI method described how to calculate the C-14 source term from neutron reactions with $\mathrm{O}-17$ and $\mathrm{N}-14$. However, the contribution from $\mathrm{N}-14$ was at least a factor of 100 less than that of $\mathrm{O}-17$, so the $\mathrm{N}-14$ term will not be considered in the calculation included in PWRGE.

Using the standard PWR neutron flux distributions (which are expected to be applicable for iPWR), C-14 will be produced at a rate of $2.475 \times 10^{-5} \mu \mathrm{Ci} / \mathrm{s}-\mathrm{kg}$. Multiplying this by the input value of mass of the primary coolant and multiplying by the appropriate conversion factors will result in $\mathrm{C}-14$ production in $\mathrm{Ci} / \mathrm{yr}$. 
The EPRI report suggests that of the C-14 produced, $90 \%$ to $98 \%$ will be released as gas, $2 \%$ to $10 \%$ as solid release, and less than $1 \%$ as liquid. Since neither GALE-86 nor GALE-09 considers solid waste, the $2 \%$ to $10 \%$ released as solid will not be considered in GALE. Also the small fraction released as liquid will not be considered in GALE. To be conservative, PWRGE will assume that $98 \%$ of the produced C-14 will be released as gas. The EPRI report further states that if there is not a recombiner in the gas treatment system then $5-30 \%$ of the $\mathrm{C}-14$ will be released as $\mathrm{CO}_{2}$ and the remaining 95-70\% will be released as organic compounds. If there is a recombiner, all of the $\mathrm{C}-14$ will be released as $\mathrm{CO}_{2}$.

Since $\mathrm{CO}_{2}$ has a greater impact on the dose than organic carbon compounds, PWRGE will assume that if there is not a recombiner, $30 \%$ will be released as $\mathrm{CO}_{2}$ and $70 \%$ will be released as organic compounds. If there is a recombiner, $100 \%$ will be released as $\mathrm{CO}_{2}$. 


\subsection{Conclusions}

A full investigation of GALE-86 and its bases was performed as they relate to the ability to model iPWR reactor designs. Although the mPower ${ }^{\circledR}$ design was the reference design for this investigation, any changes proposed as a result of this investigation are designed to make the GALE codes applicable to any iPWR reactor design. As a result of this investigation, several areas were identified as areas that need to be changed to increase the applicability of GALE-86 to iPWR designs. Each of the required changes and the calculations needed to support these changes were described.

PNNL recommends that the following changes be made to the PWR GALE codes to make them applicable to the mPower ${ }^{\circledR}$ design and other iPWR designs:

- changes already made and documented in GALE-08 and GALE-09

- addition of new nuclides to GALE output

- hardwired parameters in GALE-09 changed to user input

- changes to GALE input and output format

- tritium production and release from plants without soluble boron

- carbon-14 production and release

In addition to the technical changes described in this report, it is noted that for the NRC to use any modified version of the GALE code, including those described in this report, there would be a need to produce an updated version of NUREG-0017 and a verification and validation package documenting the proper operation and results of the revised code. This updated NUREG would include at least two sample problems (liquid and gaseous) for users to confirm the proper installation of the code on their PC

operating platforms. The preparation of this documentation would require additional effort, however, it is noted that a draft revision of NUREG-0017 has already been prepared by PNNL for the NRC Office of Research to describe GALE-09 and it bases and could be revised to include the additional recommendations from this report. 



\subsection{References}

ANS 18.1-1999, “American Nuclear Society Standard Radioactive Source Term for Normal Operation of Light Water Reactor.” American Nuclear Society, September, 1999.

ANS 18.1-1984, “American Nuclear Society Standard Radioactive Source Term for Normal Operation of Light Water Reactor.” American Nuclear Society, September, 1984.

ANS-55.6-1993 R 2007, “American Nuclear Society Standard for Liquid Radioactive Waste Processing System for Light Water Reactor Plants.” American Nuclear Society, July, 1993, Reaffirmed 2007.

Bangart, R.L., L.G. Bell, J.S. Boegli, W.C. Burke, .Y. Lee, J. L. Minns, P.G. Stoddart, R.A. Weller, J.T. Collins. 1978. Calculation of Releases of Radioactive Materials in Gaseous and Liquid Effluents from Boiling Water Reactors (BWR-GALE Code). NUREG-0016 Rev. 1, United States Nuclear Regulatory Commission, Washington D.C.

Chandrasekaren, T., J.K. Lee, and C.A. Willis. 1985. Calculation of Releases of Radioactive Materials in Gaseous and Liquid Effluents from Pressurized Water Reactors. NUREG-0017 Rev. 1, United States Nuclear Regulatory Commission, Washington D.C.

Geelhood KJ. 2009. Recommended Updates to GALE Reactor Effluent Codes. PNNL-18957, Pacific Northwest National Laboratory, Richland, Washington.

Geelhood KJ, MR Mitchell, and JG Droppo. 2008. Sensitivity Analysis of Hardwired Parameters in GALE Codes. PNNL-18150, Pacific Northwest National Laboratory, Richland, Washington.

Ludwig, S. B., J. P. Renier, Standard- and Extended-Burnup PWR and BWR Reactor Models for the ORIGEN2 Computer Code, ORNL/TM-11018 (December 1989).

Kim, K. 2010. Estimation of Carbon-14 in Nuclear Power Plant Gaseous Effluents, 1021106, Electric Power Research Institute, Palo Alto, California.

SCALE: A Comprehensive Modeling and Simulation Suite for Nuclear Safety Analysis and Design, ORNL/TM-2005/39, Version 6.1, Oak Ridge National Laboratory, Oak Ridge, Tennessee, June 2011.

US NRC - U.S. Nuclear Regulatory Commission. 2001. Design, Inspection, and Testing Criteria for Air Filtration and Adsorption Units of Normal Atmosphere Cleanup Systems in Light-Water-Cooled Nuclear Power Plants. Regulatory Guide 1.140 Rev. 2, U.S. Nuclear Regulatory Commission, Washington D.C.

US NRC - U.S. Nuclear Regulatory Commission. 1979. Design, Testing, and Maintenance Criteria for Normal Ventilation Exhaust System Air Filtration and Adsorption Units of Light-Water-Cooled Nuclear Power Plants. Regulatory Guide 1.140 Rev. 1, U.S. Nuclear Regulatory Commission, Washington D.C.

Vance JN, JE Cline, and DE Robertson. 1995. Characterization of Carbon-14 Generated by the Nuclear Power Industry. EPRI-TR-105715, Electric Power Research Institute, Palo Alto, California. 
Whelan, G., Geelhood, K., Collins, B., Rutz, F., and Droppo, J. 2008. Review of the Structure of the PWR-GALE and BWR-GALE Codes, PNNL-18091. Pacific Northwest National Laboratory, Richland, Washington.

WIMS: A Modular Scheme for Neutronics Calculations, ANSWER/WIMS (99) 9, The ANSWERS Software Package, AEA Technology.

X-5 Monte Carlo Team, 2003. MCNP - A General N-Particle Transport Code, Version 5 - Volume I: Overview and Theory, LA-UR-03-1987, Los Alamos National Laboratory, Los Alamos, New Mexico.

Yim MS and F Caron. 2006. "Life cycle and management of carbon-14 from nuclear power generation.” Progress in Nuclear Energy, vol. 48, pp. 2-36. 



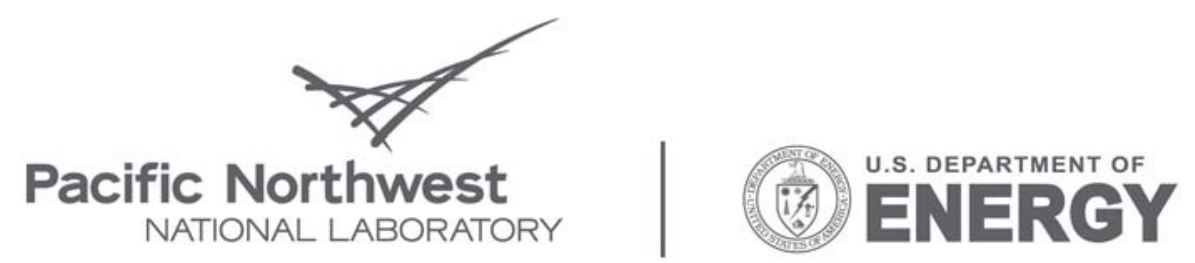

Proudly Operated by Battelle Since 1965

902 Battelle Boulevard

P.O. Box 999

Richland, WA 99352

1-888-375-PNNL (7665)

www.pnl.gov 